\title{
Contextualizing Legal Norms: A Multi-Dimensional View of the 2014 Legal Capital Reform in China
}

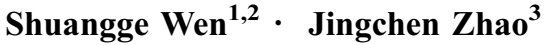

(C) The Author(s) 2017. This article is an open access publication

\begin{abstract}
This paper intends to shed light on the contentious theme of the reception of legal transplantation in the host environment, by examining the 2014 legislative reform of legal capital in China, which at least on paper imitates the enabling settings of US Revised Model Business Corporation Act (RMBCA). The paper looks at the interconnections between national-specific contextual elements, the resultant complexities, and the spillover effects of transplanted configurations in the unique Chinese socio-cultural setting, implicating the discrepancy between the 'law in practice' and the borrowed words 'on the books', and suggesting the importance of gaining a holistic understanding of 'law' involving the legal traditions in both the donor country and the recipient nation.
\end{abstract}

Keywords Legal transplantation · China - Company Law · Legal capital · Instrumentality

Shuangge Wen

shuanggewen@jlu.edu.cn

Jingchen Zhao

jzhao@leeds.ac.uk

1 Professor in Law, School of Law, Jilin University, Changchun, People's Republic of China

2 Member of International Institute of Shipping and Trade Law, Swansea University, Swansea, UK

3 Associate Professor in law, Centre of Business Law and Practice, University of Leeds, Leeds, UK 


\section{Introduction}

'East is East and West is West, and never the twain shall meet'. ${ }^{1}$ The insurmountable divide between the East and the West described by Kipling over a century ago has, at least in form, been mitigated in the contemporary practice of law and development in China. ${ }^{2}$ Future legal scholars, looking back at the development of Chinese company law legislation from 1978 to the new millennium, will note that the law has been positively open to foreign influences to a degree unimaginable in previous times, particularly 'common practices in advanced market economies in the West', and legislative changes concerning legal capital are no exception. ${ }^{3}$ While a formal and obligatory ex ante legal capital framework was initially expounded in China's 1993 Company Law regime, light-years away from the enabling company law regime prevalent in advanced market-based economies, subsequent reforms in 2005 seemed to be increasingly moving in this direction. In particular, in the latest 2014 reform the Chinese seemed ready for a bigger dose of market liberalism, taking on the essence of the so-called Washington Consensus ${ }^{4}$ : the abolition of regulations that impede the entry of new firms or restrict competition. Over three days leading up to 1 January 2014 an approved revision to the 2005 Company Law, albeit brief, unveiled a significant reform to China's market entry system. Departing from its conventional civil law preference for ex ante legal capital rules, ten company law provisions, all relating to the raising of capital, were either amended or abolished, including the removal of minimum capital thresholds, the simplification of capital contribution requirements, and the abolition of independent evaluation of capital injections. ${ }^{5}$

Echoing the powerful rhetoric of aligning Chinese corporate law more closely with that of other developed economies, much scholarly ink has been spilled in China commending this legislative change as the 'legal cornerstone underpinning China's future economic development ${ }^{6}$ and advocating its effectiveness in

\footnotetext{
1 Rudyard Kipling, 'The Ballad of East and West', The Pioneer, 2 December 1889, quoted in Winefield (1987), p 1.

2 The poem as a whole emphasized commonality and equal respect for cultures of the East and the West, rather than highlighting their differences. Carrington (1955), p 136.

3 Qiu (2006).

4 '[...] The term "Washington Consensus" [...] has come to refer to development strategies focusing around privatization, liberalization, and macro-stability; a set of policies predicted upon a strong faith [...] in unfettered markets and aimed and reducing, or even minimizing the role of government.' J.E. Stiglitz, 'The Post Washington Consensus Consensus', The Initiative for Policy Dialogue 1, http:// policydialogue.org/files/events/Stiglitz_Post_Washington_Consensus_Paper.pdf.

5 Provisions subject to revision are now found as Arts. 7, 23, 26, 32, 58, 77, 80, 83, 177 of Zhonghuarenmingongheguo Gongsifa (中华人民共和国公司法) [The Company Law of the People's Republic of China] (promulgated on 29 December 1993 and effective 1 July 1994, amended in 1999, 2004, 2005 and 2013) [hereinafter Company Law 2013], http://www.fdi.gov.cn/1800000121_39_4814_ 0_7.html. Art. 29 of the 2005 Company Law was abolished. See Zhonghuarenmingongheguo Gongsifa (中华人民共和国公司法) [Company Law of the People's Republic of China] (promulgated on 29 December 1993 and effective 1 July 1994, amended in 1999, 2004, and 2005) [Company Law 2005], Art. 29, http://www.saic.gov.cn/zw/zcfg/fl/201206/t20120612_215532.html.

6 Liu (2013).
} 
prompting the growth of the private economy. Furthermore, portrayed as a borrowing from the US legal capital regime, many also see this legislative change as an infusion of Anglo-American liberal market values, hoping that it will cure China's enduring problems of administrative interference and multiple lines of command over economic activities. ${ }^{7}$

Choruses of praise notwithstanding, the fit of these US-inspired legal capital rules within the Chinese context thus far has not been given adequate thought. The passage of these amended rules intrinsically rests upon the powerful metaphor of the 'legal transplant', ${ }^{8}$ holding that laws associated with advanced market economies are an autonomous set of formal, apolitical rules unconstrained by political and cultural borders, which can function and bring about analogous market development in developing countries, just as in the case of China. ${ }^{9}$ Indeed, both the process and the content of China's 2014 legal capital amendments implicate transplanting attempts: the US Revised Model Business Corporation Act (RMBCA) was explicitly referred to as a good model of law on capital provision in the process of this legislative reform, and the finalized version of the revision bears strong imprints of the RMBCA enabling setting, by striving to provide maximum elasticity to equity claimants by the elimination of capital provision restrictions. ${ }^{10}$

In the meantime, one has to appreciate that even today under the ever-increasing force of globalization, in many aspects China remains a metaphor for notable difference, distinct from its Western counterparts: the fact that State-owned Enterprises (SOEs) continue to dominate primary and pillar industries of the economy and enjoy privileges in various aspects challenges key assumptions of the free market economy and the hegemony of economic liberalism. ${ }^{11}$ Rooted in Confucianism and reflecting Marxist theory, the dominant instrumental view of law as a means of securing the reign of public ownership of the means of production, represented and exerted by the Party-State, also sets its face against the 'multibillion-dollar rule of law' ${ }^{12}$ concept that Western legal scholars have come to hold dear. Scholars have developed widely touted labels such as the 'Beijing Consensus', a 'China Model', or 'Chinese exceptionalism'13 to encapsulate China's unique mode of development. Although the provenance of such uniqueness remains debatable, it has been contended that the ideologically inspired Party-State control over economy and law is one major factor in the list of distinctive 'Chinese characteristics'. ${ }^{14}$ The fact that transplanted legal capital rules are embedded in a complex economic, political and

\footnotetext{
7 Ibid.

8 Teubner (1998).

9 Gillespie (2002), p 644; Lan (2014), p 367.

${ }^{10}$ Liu (2013); Cui (2014), p 151; Zhao (2014), p 19. For discussions of the benefits of the US capital provision regime, see Enriques and Macey (2001), p 1173.

11 John Williamson, 'The Washington Consensus as Policy Prescription for Development', a lecture in the series 'Practitioners of Development' delivered at the World Bank, 13 January 2004.

12 Peerenboom (2010a); Tomasic (2015), p 285; Grosman et al. (2016), p 201.

13 E.g. Kennedy (2010); Breslin (2011), pp 1323-1324; Tang (2016); Naughton (2010).

14 Peerenboom (2006), pp 825-826.
} 
ideological system that is unique and distinct from its Western counterparts provides compelling reasons for rethinking their practical effectiveness.

Building upon and complementing existing doctrinal research on legal capital reform, this paper aims to explore in depth the fit of the US-inspired legal capital rules in the Chinese corporate law context from doctrinal, ideological, and practical perspectives, and to shed some new light on the contentious debate of legal transplantation from China's legislative amendment experience. On a broad spectrum, decades of research have yet to arrive at a coherent view of the general theme of legal transplantation, with two main schools of thought forming the polar extremes of the discourse. On the one hand, advocates hold to the rhetoric of the mobility of law, suggesting that 'the amount of innovation in law is small and borrowing and imitation is of central importance in [...] the course of legal change'. ${ }^{15}$ Endorsed by multilateral organizations such as the IMF and the World Bank, core commercial law principles and governance structures associated with a mature market-oriented economy are regarded by convergence theorists as universally applicable. ${ }^{16}$ While not explicitly stated, the mobility of law hints at a formalist understanding, viewing laws as autonomous, apolitical rules that can be applied by neutral judges, unconstrained by either national, political or cultural borders. ${ }^{17}$ This nomadic vision of law also works to combat the criticism of developed countries interfering with the internal affairs of developing nationsafter all, legal transplantation is more a matter of borrowing for developing countries and an exportation process for advanced economies. As such, contemporary legal transplantation discussions tend to focus on subjects in the private law realm, so as to marginalize the social and political embedding of legal transplants. Rules on the raising and maintenance of capital, emulating the market-based ideology that commercial law is not a political form of law, are thus well received as part of the transplantation package. ${ }^{18}$

A contrasting theme, originating from Montesquieu's thesis, ${ }^{19}$ perceives law as a 'fait social total' ${ }^{20}$ that cannot supersede cultural boundaries. This school of thought was reinforced by the development of path dependence theory, which advocates long-lasting national systematic differences in the ideological, institutional, and economic compositions of home and host countries. ${ }^{21}$ As such, mobility opponents do not hesitate to use strong vocabulary to denote transported rules in the host context, describing them as "contaminants" ${ }^{22}$ or 'irritants" ${ }^{23}$ to the host country's

\footnotetext{
15 Örücü (2006), p 206.

16 E.g. Hansmann and Kraakman (2000-2001). Black and Kraakman (1996).

17 Legrand (1997), p 112.

18 Ramsay (2001), p 572; Horowitz (1977), Chapter VII, p 211.

19 As Montesquieu commented, 'The political and civil laws of each nation must be proper for the people for whom they are made, so much so that it is a very great accident if those of one nation can fit another'. De Secondat (2001); Orts (2001).

20 Mauss (1995), pp 274-275 quoted in Legrand (1997), p 116.

21 E.g. Bebchuk and Roe (2000).

22 Örücü (2006), p 210.

23 Teubner (1998), p 12.
} 
system. Meanwhile, it must be appreciated that even in the eyes of many comparative lawyers who hold to Montesquieu's thesis, sociological factors would not impact on all transplanted subjects. There would likely be socio-cultural barriers when transplanted laws relate to contextually-sensitive subjects, such as family law in the private sphere and constitutional arrangements in the public realm. ${ }^{24}$ However, when it comes to corporate and commercial law, a matter 'so very remote from the sociological and cultural essentials of life', ${ }^{25}$ Montesquieu's contention of the match between local conditions and the law will most likely lose its force.

While the fit of a transplanted foreign norm in general, and the applicability of the US-inspired legal capital rules in China in particular, are matters of controversy, which can lead to distinct conclusions of a half-full or a half-empty glass depending on one's subjective stance, ${ }^{26}$ at least three considerations help one gain an insight into the fit and feasibility of legal transplantation. First, there is the issue of the purpose of legal borrowing, i.e. the role that a transplanted norm is expected to serve in the host country. Although some might imagine the needs of the borrowing country to be the same as those of the source society, practice has shown that this is rarely the case. ${ }^{27}$ Second, the borrowing society's distinguishing economic, political, and social institutions, which the transplant will be rooted in, are a significant factor. A complex interplay between the transplant and socio-cultural forces may well cause the transplant process to be far from straightforward. Third, there will likely be additional consequences of the transplanted rule when it seeps into the idiosyncrasies of the new legal environment, i.e. possible spillovers to connecting areas. When the background social institutions are different, using regularities and tendencies in the original context to predict future effects in a new environment has often proved premature. ${ }^{28}$

As noted by a Chinese slogan: tiny clues help reveal the general trend. ${ }^{29}$ One major goal of this paper is to subject the feasibility of legal transplantation to critical scrutiny; and the recent legislative change surrounding legal capital in China will be used to evaluate the conventional vision of 'Commercial-law-as-bare-rules' ${ }^{30}$ with regard to the above stated three aspects. Beginning with an overview of the doctrinal disparities pertaining to legal capital between the US and China's conventional frameworks in Sects. 2, 3 affords a discussion of the national-specific imperatives

\footnotetext{
${ }^{24}$ For instance, Kahn-Freund used Japan as an example in distinguishing commercial law and family law subjects when it comes to the feasibility of legal transplantation. 'Before the First World War Japan adopted the German law of contract, of civil delict and of property, but the principles of family law only with modifications, and even as modified, we are told, they largely failed to mould the "law in actual operation" as distinct from the "law in books". Kahn-Freund (1974), p 7.

25 Ibid., at $\mathrm{p} 4$.

26 Örücü (2002), p 209; Clarke (2006), p 1, 'At what point do we say that a norm is so new, and its source so different, that it counts as a transplant into a particular body of law, and not simply an internal development of that body of law?'.

27 Clarke (2006), p 2.

28 Bix (2012), p 16.

29 I.e. Jian Wei Zhi Zhu (见微知著). Zhang and Wang (2014), p 96.

${ }^{30}$ Legrand (1997), p 114, '[...] Anyone who believes in the reality of "legal transplants" must [...] accept, in particular, a "law-as-rules" and a "rules-as-bare-propositional-statements" model'.
} 
underpinning the trajectory of legal capital reforms in China. The socio-economic agendas associated with the 2014 reform are set out in detail, illustrating the political-economic dynamics of corporate law making in China. Section 4 focuses on the doctrinal perspective, and examines the fit of 2014 legislative amendments to existing legal settings, and potential loopholes generating therefrom. Section 5 examines the force of socio-cultural specialties in shaping the distinct nature of laws in a comparative manner, in particular, the roots of the instrumentality view of law and the State centrality underpinning the process of the 2014 legal capital reform in China, in contrast to the US orbit where the transplanted rules originated. Section 6 sketches the contours of potential spillovers resulting from the latest legal capital reform within the national-specific embeddings discussed in Sect. 5-or, in metaphorical language, practical irritations resulting from transplantation. Section 7 offers further reform suggestions and the last section concludes. Although the latest legal capital reform is envisaged to stimulate private entrepreneurship and liberalize the economy as it does in advanced market-based economies, viewed through a broader socio-economic lens it functions as part of a relatively well-trodden, measured sequence of State-led reforms of the economy in China, ${ }^{31}$ distinct from the economic liberal wisdom from which these transplanted arrangements derived. Conventional ideological and institutional factors specific to the Chinese socioeconomic setting also affect the functions of these transplanted rules, making them unlikely to become fully purposive.

\section{The Trajectory of Legal Capital Reforms in China}

\subsection{An Overview of the Conception of Legal Capital}

Company law in almost every jurisdiction makes certain implicit assumptions: that the limited liability of shareholders creates a tension between their interests and those of creditors; that this tension cannot be fully resolved by contractual means between the two sides; and that corporate directors are tempted to maximize the interests of shareholders by expropriating creditors, particularly when the company is approaching insolvency. From this point of view, mandatory arrangements in relation to legal capital initially came to light as a reaction to the inauguration of limited liability and the disturbed equilibrium between the interests of shareholders and creditors. ${ }^{32}$ These rules were justified as the price paid by shareholders for their access to limited liability —or, from the creditors' perspective, a trust fund held by a limited liability corporation to discourage shareholders' opportunistic conduct, in exchange for the loss of their right to hold shareholders personally liable for debts. ${ }^{33}$

\footnotetext{
31 This has been termed 'economic Statism' in certain literature sources. E.g. Breslin (2011), p 1327; Kennedy (2010), p 461.

32 Kohl (1999), p 196.

33 Wood v. Dummer 30 F. Cas. 435 (C.C.D.Me. 1824). This 'trust fund' argument has lost much of its appeal in the contemporary US owing to two major concerns. First, it is argued that the initial amount of share capital cannot reflect either post-incorporation changes to corporate assets, or the actual financial condition of the firm. It thus bears no relevance to either the business reality or the intended protection of
} 
The main utility of legal capital mandates was thus claimed to protect creditors, preventing the unlawful transfer of assets from the company to its members.

While there are many legislative and practical variations, available legal capital mandates have been mainly structured around two pillars: the principle of capital provision, i.e. shareholders must make genuine and adequate capital contributions to the company in the manner they promise in the articles of incorporation; and the principle of capital maintenance, i.e. the company must not distribute assets to the shareholders to the detriment of the creditors. ${ }^{34}$ Viewed from the company's perspective, capital provision ensures a proper inflow of share capital into the company, and capital maintenance prohibits the unlawful outflow of assets from the company. In addition to the plethora of laws embodying these two themes, minimum capital thresholds are prescribed in certain jurisdictions, requiring a minimal amount of registered capital from shareholders at the time of incorporation. The practical effectiveness of such thresholds depends heavily on the integral enforcement of laws governing the provision and maintenance of capital, though the implementation of the latter two aspects is relatively independent of the presence of a minimum threshold, an arbitrary figure prescribed by law.

\subsection{Doctrinal Disparities between Two Major Legal Capital Frameworks}

In conjunction with a multitude of economic and social developments, contemporary views on legal capital have gradually polarized around two major camps, classifying the ideal types of company laws into those which are enabling and those which are regulatory. ${ }^{35}$ The first camp, represented by the United States and the United Kingdom, generally emphasizes the enabling role of company law, arguing for the autonomy of private entrepreneurs and thus the demise of mandatory restrictions on the provision and maintenance of capital. ${ }^{36}$ While the UK is still

\footnotetext{
Footnote 33 continued

creditors, because of its primitive and inaccurate indication of the company's ability to pay its debts. Second, the restraining effect of minimum capital on startup companies can be massive. As entrepreneurs who are unable to satisfy the minimum threshold will not be able to benefit from limited liability, this creates practical barriers to market entry and indirectly favors existing firms by reducing their competitive pressures. This view of restraining startups stands at odds with the Anglo-American liberal ideology of 'competition in a free market'. See Enriques and Macey (2001), p 1166; Hassen (2009), p 73.

34 Allen et al. (2009), pp 139-140; Armour (2000), p 365.

35 This categorization to a large extent connects with the taxonomy of corporate law and governance systems in comparative literature. The Anglo-American system, generally regarded as including the United States and the United Kingdom, and the Continental system exemplified by Germany, are commonly seen as forming the two polar extremes. E.g. Williams and Conley (2005); Toms and Wright (2005). Anglo-American company laws are generally regarded as more liberal, allowing entrepreneurs to order their affairs with minimal State interference. This is in stark contrast to the prescriptive nature of Continental laws. Sealy and Worthington (2010), p 52. Although legal capital settings in English law remain primarily enabling for private companies, stricter rules are in place for public companies following the Second EC Company Directive requirements. For the purpose of this article, US laws as regards legal capital will be primarily employed when discussing the enabling ideology of company law.

36 E.g. Department of Business, Innovation \& Skills (2012), p 5: 'The company law framework is enabling'.
} 
obliged to retain certain capital restrictions in line with EU requirements, ${ }^{37}$ the depletion of mandatory capital provision rules has reached its pinnacle in the US, the RMBCA being a typical example. Concepts of stated capital and par value have been criticized as 'outmoded' 38 and abolished, rendering the question of watered stock, i.e. the inadequacy of consideration for shares, largely a dead issue in the eyes of US lawyers. ${ }^{39}$ When it comes to appraising in-kind payments, the RMBCA, honouring party autonomy, affords the conclusive right of determination to the board of directors without asking for independent expert valuation. ${ }^{40}$ An evident overvaluation of an in-kind asset is seen as a matter for shareholders rather than for creditors, which may be corrected by ex post court review as the result of an action filed by shareholders. ${ }^{41}$

Likewise, "the simplest of all the modern statutory limitations ${ }^{42}$ to capital maintenance can now be found in the RMBCA, and they are all broadly constructed as restrictions on dividend distributions, considering their functional equivalence on the company's balance sheet. ${ }^{43}$ The scope of distribution is widely defined to include not only traditional cash dividends, but virtually all transfers of money or other property to a shareholder. ${ }^{44}$ On paper these distribution restrictions are supposedly premised on dual equity and balance sheet standards, revealing the lynchpins of corporate financial status-assets and cash flow. ${ }^{45}$ In the meantime, entrepreneurs are afforded flexibilities to get around these mandatory restrictions, hinting at the enabling rather than restraining nature of corporate laws. For instance, in determining whether corporate assets suffice to make distributions under this dual test, the RMBCA grants boards wide discretion, permitting them to rely on either

\footnotetext{
37 These EU mandatory restrictions on legal capital mainly concern public limited liability companies. See Council Directive 2012/30/EU of the European Parliament and of the Council of 25 October 2012 on Coordination of Safeguards which, for the Protection of the Interests of Members and Others, are required by Member States of Companies within the Meaning of the Second Paragraph of Art. 54 of the Treaty on the Functioning of the European Union, in respect of the Formation of Public Limited Liability Companies and the Maintenance and Alteration of Their Capital, with a view to Making such Safeguards Equivalent Text with EEA Relevance, Preamble (3) and Art. 1, [2012] OJ L 315 [Council Directive 2012/ 30/EU].

38 Committee on Corporate Laws (1979), p 1867, suggesting the abolishment of the 'outmoded concepts of stated capital and par value' and liberalized rules on profit distribution and share repurchases.

39 Revised Model Bus. Corp. Act $\S 6.21$ (b) and (c), stating that shares can now be issued for consideration 'consisting of any tangible or intangible property to benefit to the corporation', and the board of directors are to decide 'that the consideration received or to be received for shares to be issued is adequate'.

40 Revised Model Bus. Corp. Act $\$ 6.21$ (c).

41 E.g. Lewis v. Scotten Dillon, 306 A 2d 755 (1973). As remarked by Lindley LJ in Re Wragg, 'The value paid to the company is measured by the price at which the company agrees to buy what it thinks is worth its while to acquire'. [1897] 1 Ch 796, p 831.

42 Bainbridge (2002), pp 78 and 776.

43 Cox and Hazen (2003), $§$ 20.09-20.10; Enriques and Macey (2001), pp 1179-1180.

44 Revised Model Bus. Corp. Act $§ 1.40$ (6) and $\S 6.40$ Official Comment 2.

45 One is the balance sheet test, which commands an excess of assets over liabilities and the claims of preferred shareholders after the proposed distribution; the other is the equity insolvency test, requiring that the company has sufficient liquid assets to meet its debts and liabilities as they become due in the following period. Revised Model Business Corporation Act $\S 6.40$ Official Comment 2-4.
} 
the generally accepted accounting principles (GAAP) or 'a fair valuation or other method that is reasonable in the circumstances'. ${ }^{46}$ The latter practically allows a corporation to write up assets to reflect an increase in their fair market value, and thus to pay a dividend despite the present state of the firm's balance sheet.

In stark contrast to the enabling approach adopted by the RMBCA, mandatory legal capital rules existing as ex ante creditor protection in Continental European regimes spring from the civil law family's great respect for legislation, ${ }^{47}$ and reflect civil law's reluctance to leave potential deficient company formation 'to the hazards of litigation'. ${ }^{48}$ In the case of China, the conventional 1993 Company Law regime, exemplifying the formal and obligatory civil law approach, also largely held on to mandatory ex ante legal capital rules: all registered capital had to be specified in the articles and fully paid up prior to the time of incorporation, ${ }^{49}$ and in-kind contributions had to be professionally valued to match the par value of the shares. ${ }^{50}$ Meanwhile, advocating many idealized functions of minimum capital, including creditor protection, transaction security, and enhancing State control over the economy, ${ }^{51}$ the 1993 Chinese Company Law also imposed rigorous thresholds of between RMB 100,000 and RMB $500,000^{52}$ as part of the rules governing the raising of initial capital. Given that the average wage of a formal employee in China in 1995 was only RMB 5500 per annum, ${ }^{53}$ these capital thresholds prescribed in the 1993 Company Law were out of reach for most ordinary Chinese people who wished to start their own businesses, largely thwarting the growth of private economy.

In addition to ex ante capital provision mandates, capital maintenance rules were also set in a meticulously doctrinal manner in China's 1993 Company Law, spreading from traditional distribution prohibition ${ }^{54}$ to categorized restrictions on the reduction of share capital, ${ }^{55}$ the company's purchase of its own shares ${ }^{56}$ and shareholders taking back their investment. ${ }^{57}$ Stringent requirements also confined the scope of assets subject to dividend distributions: the losses of previous years were to be made up by current profits; $10 \%$ of the company's after-tax profits were to be drawn out as the company's statutory common reserve; and another 5-10\% of

\footnotetext{
46 Revised Model Bus. Corp. Act $\$ 6.40 \mathrm{cmt}$. b.

47 Dainow (1967), p 424.

48 Kahn-Freund (1974), p 65.

49 Companies Law of the People's Republic of China (promulgated by the Standing Comm. Nat'l People's Cong., 29 December 1993, effective 1 July 1994) [hereinafter Company Law 1993], Art. 25.

50 Ibid., Art. 24.

51 Wang (2012), p 177.

52 Company Law 1993, above n. 49, Art. 23.

53 National Bureau of Statistics of China, China Statistical Database-Average Wage of Formal Employees by Sector (end of 1995), http://www.stats.gov.cn/english/statisticaldata/yearlydata/YB1996e/ D4-26e.htm (accessed 18 July 2015).

54 Company Law 1993, above n. 49, Art. 177.

55 Ibid., Art. 186.

56 Ibid., Art. 149.

57 Ibid., Art. 34.
} 
the company's profits were to be set aside as the company's statutory welfare reserve for employees, all before any distribution could be made to shareholders. ${ }^{58}$ The scope of corporate assets subject to capital maintenance restrictions in China was thus much wider than its counterpart under the RMBCA, in the sense that a substantial amount of the company's profits would not be available for distribution, even after satisfying the US dual adequate solvency tests.

\subsection{Reforms to the Legal Capital Regime in China}

After the inauguration of the 1993 legal capital regime, detailed rules concerning capital provision have undergone two further reforms in 2005 and 2014 to encourage private entrepreneurship, as China has moved to reform its socialist economy to be more responsive to market forces. Two key aspects of the 2005 company law reform notably evidenced such pro-market inclination: (1) the minimum capital thresholds lowered considerably, from at least RMB 100,000 to RMB 30,$000 ;^{59}$ and (2) a significant reduction of the amount of initial capital contribution was also seen-from full initial subscription of the registered capital to no less than $20 \%$ to be contributed at the time of corporation. ${ }^{60}$ The latest 2014 legal capital changes went further in liberalizing capital formation, bearing the hallmarks of the US RMBCA enabling ideology in three major aspects. First, the traditional regime based on paid-in capital has now changed to one based on subscribed capital, with minimum paid-in thresholds completely discarded. ${ }^{61}$ Second, forms of capital contribution have also been made more flexible and variable by completely removing the cash contribution threshold-investors are now entitled to make full in-kind capital contributions at their discretion, including IP rights, domain names, equipment and so on. ${ }^{62}$ Furthermore, a significant streamlining of the administrative requirements is also seen-detailed information in relation to capital contribution, including the unpaid amount of share capital, the amount to be paid up at the time of registration, and the time period for each shareholder to pay up his subscribed capital, is no longer required to be checked by Industry and Commerce authorities or recorded on the business license. ${ }^{63}$ The conventional requirement of an independent verification report submitted to the registration authority for each capital injection is no longer necessary either, leaving the right of determination of the value of in-kind capital contributions completely to the business judgment of the board. ${ }^{64}$

\footnotetext{
58 Ibid., Art. 177.

59 Company Law 2005, above n. 5, Art. 26.

60 Ibid., Art. 26.

61 In the US, mandatory capital provision rules have by and large fallen into disuse, with RMBCA completely abolishing concepts of stated capital and par value. Revised Model Bus. Corp. Act $\S 6.21$, Official Comment.

62 Company Law 2005, above n. 5, Art. 27; Company Law 2013, above n. 5, Art. 27. For the RMBCA perspective see Revised Model Bus. Corp. Act $\$ 6.21$ (c).

63 Company Law 2013, above n. 5, Art. 7.

64 Company Law 2005, above n. 5, Art. 29, now removed by the Company Law 2013. Also Revised Model Bus. Corp. Act $\S 6.21$, Official Comment.
} 


\section{Goals of Legal Transplantation-The Instrumentality of Legal Capital Reforms in China}

\subsection{A Formalist Unification of Law}

As one of the basic pillars encouraging private entrepreneurship and market competition, the trajectory of legislative reforms concerning legal capital in China demonstrates the increasing inclination of Chinese company law towards the AngloAmerican market-oriented model, alongside other reforms of company law. ${ }^{65}$ Against the backdrop of the Law and Development Movement which has dominated in past decades, seeking to promote an international order of economic and social institutions similar to those in more advanced economies, ${ }^{66}$ some scholars suggest that the first and foremost purpose of such burgeoning borrowing activities in China is to prepare for the international unification of law amid globalization. ${ }^{67}$ Indeed, it is hard to overlook the enthusiasm of Chinese legislators learning from the West, in line with China's position poised to engage more with the world economy. ${ }^{68}$ Appreciating that the nation's relative lack of experience of marketization has not been adequate to distil a complete set of normative standards in the field of company and commercial law, it was also logical for Chinese lawmakers to turn to legal systems in mature market-oriented economies for inspiration. Drawing on laws from the US, a representative country of the Western advanced economies, the reform of legal capital rules is thus commended (and hoped) by legislators as one of the forward steps towards conforming to international business standards in advanced market economies. As remarked by Junhai Liu, a scholar sitting on the legislative committee, the 2014 legislative change surrounding capital provision is both necessary and urgent in the sense that it is already more than thirty years later than the reform in the US'. ${ }^{6}$

\subsection{The Instrumentality of Legal Capital Lawmaking in China and Political- Economic Dynamics of the 1993 and 2005 Reforms}

While appreciating the force of globalization in inducing legislative changes and the inherent formalist view of law that legal transplants associated with the marketbased economy can induce analogous market reforms in developing countries, ${ }^{70}$ one

\footnotetext{
65 Another significant company law field that exerted an increasing Anglo-American influence is directors' duty. See Xi (2006), p 28.

66 Ginsburg (2000), p 829; Tamanaha (1995), p 471.

67 Kahn-Freund has identified three prime purposes of legal transplantation, namely, 'first, with the object of preparing the international unification of the law, secondly, with the object of giving adequate legal effect to a social change shared by the foreign country with one's own country, and thirdly, with the object of promoting at home a social change which foreign law is designed either to express or to produce.' Kahn-Freund (1974), p 2.

68 Allen et al. (2005), pp 57-116, at p 64.

69 'Gongsifa Xiugai Ersan Yan' (公司法修改二三言) [Several Comments on the Reform of Company Law], (2014) 10 Pinming, http://www.civillaw.com.cn/Article/default.asp?id=60050. See also Li (2015), p 193.

70 Gillespie (2002), p 644.
} 
should not undermine analytical rigor by eliding the force of complex contextual specifics in China. These are displayed in the political-economic dynamic and the instrumental nature of corporate law making, best summarized by Chairman Zedong Mao: "[laws are] instruments with which one class oppresses another [...] They are violent and certainly not "benevolent things". 71 This is particularly the case in the field of legal capital. Given its anticipated effect in accelerating private economy growth, the rhetoric of reforming, and particularly of removing, restraints on capital provisions potentially stands at odds with the overriding political theme of ChinaMarxist-Leninist socialism. In an ideal Marxist communist society, the concept of private ownership of the means of production would be abolished because of its basis in 'class antagonism, on the exploitation of the many by the few'. ${ }^{72}$ The concept of property will eventually be conferred a social character and converted into common holdings of all members, so as to do away with personal appropriation. ${ }^{73}$ During the Maoist era (from 1949-1978, the so-called first thirty years of China's development), Chinese Communists mainly emphasized the ideological differences between communism and capitalism, and the roles of states and markets were heavily politicized and branded as the 'Socialist East'/'Liberal West' conflict, or as part of the 'long if often dubious history' of 'East-West comparisons' ${ }^{74}$ For this reason, Chinese law relating to enterprise organizations barely existed prior to the 1978 economic reform. ${ }^{75}$ Given their affiliation with the development of private business enterprises, classified as 'capitalist forms of industrial organizations, ${ }^{76}$ the concept of legal capital and accompanying company law provisions were nowhere to be found during the Maoist period, and did not enter into China's legal system until 1993, owing not least to the politically sensitive nature of this subject.

In the late 1970s China initiated an overall economic turnaround towards a marketbased paradigm led by the Party-State. ${ }^{77}$ This economic policy shift was inventively

\footnotetext{
71 Zedong Mao (1927) 'Hunan Nongmin Yundong Kaocha Baogao' (湖南农民运动考察报告) [The report on Hunan peasant movement], http://www.china.com.cn/guoqing/2012-08/29/content_26367138. htm.

72 Marx and Engels (1996), pp 102-105.

73 As stated by Marx and Engels, '[...] [T]he theory of the Communists may be summed up in the single sentence: Abolition of private property.' Ibid., pp 102 and 103.

74 Peerenboom (2003), p 2.

75 Clarke (2006), at p 4. For this reason, private business activity was practically out of law for decades in China since the Communist Party took over in 1949. Prior to the 1978 economic opening up, the only economic sector allowed was public ownership, with the State-owned economy accounting for $77.6 \%$ and the Group-owned economy accounting for 22.4\%. See 'Duozhong Jingji Chengfen Bingcun' (多种经济 成分并存) [The Existence of Many Types of Economic Sectors], in The Summary of China 2007, http:// www.china.com.cn/aboutchina/zhuanti/2007zgjk/2007-11/12/content_9214613.htm.

76 Clarke (2006), at p 3.

77 Chaobin Wang, 'Cong Jihuajingji dao Shehuizhuyi Shichangjingji de Weida Biange' (从计划经济到 社会主义市场经济的伟大变革) [A Great Transformation from the State-Planned Economy to Socialist Market Economy], 11 Xinxiang Review (2008), http://cpc.people.com.cn/GB/68742/127229/127250/ 8344596.html (accessed 18 July 2016). At the Plenary Session of the Communist Party Central Committee in 1984, the central committee indicated that the ownership and management of state-owned enterprises may be appropriately separated. This was codified in 1988, in the Law on Industrial Enterprises Owned by the Whole People. See Art and Gu (1995), pp 278-279.
} 
justified by the accompanying ideological development emphasizing another aspect of Marxist theory, i.e. economic determinism describing the correlation between the material 'base' and the ideological structure of a society that embraces all political, legal, and cultural institutions. ${ }^{78}$ Since the opening up and reform in 1978 (or the second thirty years, as it was described by the Chinese press), socio-economic development in China has exhibited an interesting trend. While many elements of the Chinese economy, including the acceptance of foreign investment, the corporatization of State-Owned Enterprises (SOEs) and the proliferation of the private economy, are endeavouring to resemble the US market-oriented regime, at least in form, in ideology these business features initiated and developed in capitalist countries are still justified under the basic tenet of the Communist Party of China, namely Party-State-led socialism. ${ }^{79}$ The State still structures and leads the process of growth, channels capital, and guides the activities of private actors. ${ }^{80}$ The making and unmaking of legal capital rules in China and the pace of subsequent reforms, including the initial 1993 mandates, subsequent relaxations concerning capital formation in 2005, and the acclaimed 2014 landmark move to the RMBCA enabling mode, have had a strong instrumental character, inevitably connecting to major shifts in economic policy developed and carried out by the State. ${ }^{81}$

The 1993 and the 2005 legal capital developments corresponded with and served the economic needs in the initial two stages of China's so-called Socialist Market Economic Reform. ${ }^{82}$ The first stage started in 1993, the central theme being the establishment of a market economy while preserving the dominating socialist theme. ${ }^{83}$ In this general climate, the major goal of the first Company Law, passed in 1993, was to oil the wheels of the State-owned sector and enable struggling Stateowned firms to raise capital from the general public, rather than to encourage the growth of private economy. ${ }^{84}$ Additional to the usual Equity Cushion function, the presence of a set of stringent rules on legal capital, particularly restrictions on capital provision, was viewed as an effective means of restricting the development of the private economy. Meanwhile, reflecting the view of Marxism that law serves as an ideological instrument of politics, ${ }^{85}$ these rules in legal capital also reinforced

\footnotetext{
78 Wacks (2012), p 179.

79 Peerenboom (2010b), p 91. 'China's reforms have been successful due in large part to the government's pragmatic approach and willingness to resist, selectively adopt, and adapt as needed the ideologically driven prescriptions offered by Western states and international donor agencies.'

${ }^{80}$ Ginsburg (2000), p 836.

81 Kennedy (2010), pp 461-462.

82 'China's Socialist Market Economic Reform and Its Strong Theoretical Consciousness and Confidence', People's Daily Online, 17 October 2012, http://english.peopledaily.com.cn/100668/ 102793/7980397.html.

83 'Zhonggongzhongyang Guanyu Jianli Shehuizhuyi Shichangjingji Tizhi Ruoganwenti de Jueding' (中 共中央关于建立社会主义市场经济体制若干问题的决定) [The Decision of the CPC Central Committee on Issues Concerning the Establishment of the Socialist Market Economy], adopted at the Third Plenary Session of the 14th Central Committee of the CPC on 14 November 1993, http://finance.ifeng. com/opinion/jjsh/20090906/1199906.shtml.

84 Chen (2003), p 451.

85 As put by Tushnet, in favor of the Marxist spirit, 'law is politics, all the way down'. Tushnet (1991), p 1526.
} 
the sanctity of Party-State power in China-companies had to satisfy requirements imposed by the State before acquiring their legal personality and limited liability benefits. Towards these ends, Chinese lawmakers unsurprisingly chose to emulate stringent ex ante capital provision rules in the 1993 Company Law regime set out in the section above, rather than the enabling mode evidenced in RMBCA.

The second stage of China's economic development began in 2003, with the central policy imperative evolving to become the so-called Improvement of the Socialist Market Economy. ${ }^{86}$ The position of private business improved markedly during this stage, formally legitimized as part of the Socialist Market Economy that China was heading towards. ${ }^{87}$ Accompanying the subtle shift in policy attitude from repressing to encouraging the private economy sector, company law in China was modified accordingly, from primarily emphasizing the governing function towards increasing reception of the market-based ideology and advocating the enabling role of company law. It is thus no coincidence that the 2005 company law reform was triggered and implemented immediately after the 2003 economic policy shift, ${ }^{88}$ symbolizing the country's commitment to encouraging private entrepreneurship in the market economy.

\subsection{The Socio-Economic Agendas of the 2014 Reform}

As presented above, a contextual rather than textual view of the 1993 and 2005 legislative moves relevant to legal capital helps to appreciate the primary nature of laws as 'an instrument' in a measured sequence of State-led reforms in China, which is different to the US legal configurations serving the economic liberalism ideal. Likewise, as will be examined in Sect. 5, the 2014 reform was more of a top-down move 'forced' by the government. Viewed from the doctrinal perspective, the 2014 legal capital reform was not as urgent and necessary as the 2005 one-the RMB 30,000 minimum threshold in the 2005 regime no longer constituted a significant barrier to the establishment of private businesses. ${ }^{89}$ The instrumentality of the 2014 legislative revision thus needs to be sought in consideration of China's immediate socio-economic agendas and immediate needs identified by the government, as detailed below.

\footnotetext{
86 'Zhonggongzhongyang Guanyu Wanshan Shehuizhuyi Shichangjiji Tizhi Ruoganwenti de Jueding' (中共中央关于完善社会主义市场经济体制若干问题的决定) [The Decision of the CPC Central Committee on Issues Concerning the Improvement of the Socialist Market Economy], adopted at the Third Plenary Session of the 16th Central Committee of the CPC on 14 October 2003, http://news. xinhuanet.com/zhengfu/2003-10/22/content_1136008.htm. Accessed 18 July 2016.

87 Ibid.

88 Calcina Howson (2010), p 136.

89 The number of private enterprises in China has risen rapidly from 23.5 million in 2004 to 40.6 million in January, 2013, implicating the enabling effect of the 2005 company law framework. See 'China Has 40.6 Million Private Businesses', MarketWatch, 10 February 2013, http://www.marketwatch.com/story/ china-has-406-million-private-businesses-2013-02-10; Li (2015), p 184.
} 


\subsubsection{Stimulating Private Entrepreneurship and Liberalizing the Economy- Demands of the Economic Structural Transition}

As with previous reforms, the primary aim of the 2014 reform identified by the Chinese government was still economically founded, i.e. 'to foster economic development' by way of stimulating the private sector. ${ }^{90}$ Undeniably, the rate of economic growth in China in the past decades has been incredible-starting from scratch, the Chinese economy has managed an average $10.06 \%$ annual growth since the economic openingup in $1978,{ }^{91}$ and even during and after the 2007-2009 financial crisis that led to the worst worldwide economic recession in seven decades, China's economy still managed above $7 \%$ annual growth. ${ }^{92}$ In the meantime, the unsustainability of the State-investment-led, export-oriented model and an urgent need for economic structural reforms was openly acknowledged by the Chinese leadership as early as 2007. ${ }^{93}$ This heavy reliance on exports has always been a 'chronic illness', ${ }^{94}$ but its harmful impact began to be really felt around the end of the last decade after the worldwide crisis, when the general economic decline in world markets led to a significant fall in export demands and a rise of labour costs in China. Although steps were taken during the $\mathrm{Hu}-\mathrm{Wen}$ administration, the first and foremost task facing the new generation leaders, led by Jinping $\mathrm{Xi}$ as the new Communist Party and military chief since March 2013, remained an engineered structural shift towards new modes of development, based less on exports and more on domestic growth and markets. ${ }^{95}$ The desired shift entails a move away from largely state-run heavy industry to more entrepreneurial and services-led growth, which is mainly provided by the private sector. ${ }^{96}$ Taking as a given rather than as an assumption that start-ups and SMEs are powerful economic drivers, the Chinese government has concluded that this cannot be achieved without more private capital investment. Inextricable from the microeconomic ideal that ' $[. .$.$] every small business is a potential Microsoft', { }^{97}$ the abolition of

\footnotetext{
90 State Council, Guowuyuan Guanyu Yinfa Zhuce Ziben Dengji Zhidu Gaige Fang'an de Tongzhi [Notice of the State Council on the Issuance of the Reform Plan to Amend the Registered Capital Registration System], Guofa (2014) No. 7, http://www.gov.cn/zwgk/2014-02/18/content_2611545.htm.

91 See World Bank Data with authors' calculation, http://data.worldbank.org/indicator/NY.GDP.MKTP. KD.ZG?locations=CN.

92 Statistics China, http://www.tradingeconomics.com/china/gdp-growth-annual.

93 'A country that appears peaceful and stable may encounter unexpected crises. There are structural problems in China's economy which cause unsteady, unbalanced, uncoordinated and unsustainable development'. Remarks from Premier Jiabao Wen's Press Conference of 17 March, 2007. Full text is available at http://www.chinaconsulatesf.org/eng/xw/t304313.htm.

94 Ding Xueliang, 'Watch Out for the Chronic Illness of the China Model' (警惕中国模式的“慢性病’), Nanfang Zhoumo, 31, 9 December 2011.

95 'To solve the long-term challenges of economic development in China, we must implement structural reform, even though we may let our economy grow at a lower rate.' Remarks made by President Jinping $\mathrm{Xi}$ at the first session of the G20 leaders summit in 2013, after he assumed power in March. See Jing Fu, Jiao Wu and Songxin Xie, 'Xi Vows Economic Reform', Chinadaily, 6 September 2013, http://www. chinadaily.com.cn/kindle/2013-09/06/content_16949683.htm.

96 Kevin Yao, 'China Needs the Private Sector to Step Up', Reuters, 16 May 2016, http://www.reuters. com/article/us-china-economy-investment-idUSKCNOY60V4.

97 Ramsay (2001), p 569.
} 
market entry requirements by way of modifying capital provision rules is thus portrayed by the new Chinese leaders as apposite at this point of time, to encourage investment in start-up companies and further prompt the growth of private economy. This motive has been repeatedly asserted by China's recent official discourse, in which the words 'small start-up businesses' and 'competitive and innovative' are frequently linked together. ${ }^{98}$ As remarked by Premier $\mathrm{Li}$, the legal capital legislative amendment is timely to 'support smaller businesses, especially innovative enterprises'. 99

Additional to stimulating domestic start-ups, this enabling-style reform also portrays the new government's determination to liberalizing the economy, and bringing to an end the practice of administrative orders superseding free markets. This works to combat common criticisms targeting China's impenetrable legacy of administrative control, thereby boosting investors' confidence in China's investment environment, and providing another powerful thrust for continuing economic growth. ${ }^{100}$

\subsubsection{Relieving Unemployment Pressures and Maintaining Social Stability}

While seemingly unconnected, the legislative change in capital provision also serves the purposes of relieving the massive unemployment pressures brought about by the upcoming economic reform and maintaining overall social stability. The fast speed of economic growth in China over the past few decades has come at a priceuneven investment and development of industrial sectors, additional to the overreliance on exportation as identified above. Since early 2000s the problem of excessive industrial production capacity has been evident, with excess capacity and utilization rates constantly below $80 \%$ in major industries over the past fifteen years. ${ }^{101}$ This issue has only become worse since the 2008 economic stimulus programs - to avoid massive business collapses and unemployment the central government injected RMB 4 trillion into the economy, with local governments launching their own stimuli with about RMB 13 trillion. ${ }^{102}$ With demand from export markets falling considerably during and after the 2008 global financial crisis, much of the above-stated economic stimulation focused on domestic construction, in the hope of increasing domestic capacity for steel, cement, and aluminium. ${ }^{103}$ With production capacities under arbitrary stimulation, the excess problem has become particularly acute when construction programs slowed down-since 2012 eight key industries, including steel, coal, cement, glass, oil, petrifaction, iron, and

\footnotetext{
98 Xiang Yangge and Ping Liu, 'State Council Announce Significant Company Registration System Reform', 14 November 2013, http://www.mondaq.com/x/274880/Insolvency+Bankruptcy/State+ Council+Announce+Significant+Company+Registration+System+Reform.

99 Ibid.

100 Ibid.

101 Mamta Badkar, 'China Stimulated Its Economy Like Crazy after the Financial Crisis... And Now the Nightmare Is Beginning', Business Insider, 17 June 2013, http://www.businessinsider.com/chinas-excesscapacity-problem-2013-6.

102 Ibid.

103 Ibid.
} 
non-ferrous metals, began to show negative growth in their Producer Price Index. ${ }^{104}$ Up to December 2015, over $80 \%$ of the businesses in these eight industries were making losses. ${ }^{105}$

Under the current State-led economic reform agenda, the story gets more complicated: despite the fact that many businesses in these overproducing industries lack commercial viability, the Chinese government has been reluctant to let them go and has forced banks to continue injecting money into them, ${ }^{106}$ because: (1) the potential consequences of mass unemployment and social instability could be devastating; and (2) many businesses in these overproducing industries are SOEs and have objectives other than profit maximization, for instance social services, tax revenues, and so on. ${ }^{107}$ Accompanying the continuing financial support of these loss-making companies has been the common phenomenon of Chinese courts refusing to accept SOE bankruptcy claims. ${ }^{108}$ An undesirable yet unavoidable consequence of these two policies is the mass appearance of 'zombie companies' in these overproducing industries, i.e. economically unviable businesses which 'have been kept alive long after they should have died thanks to money poured in by governments and banks'. ${ }^{109}$ In the meantime, the increase of non-performing loans and bad debts generated by these businesses has placed huge pressures on Chinese banks, leading to a 'cash crunch' crisis in the past few years. As statistics reveal, China's corporate debt market is now the world's largest at $\$ 14.2$ trillion, and it is still expanding 'at a lightning-fast rate' ${ }^{110}$ With 'the banks [...] short on cash, [and] the stock market and small- and medium-sized enterprises [...] short on cash', ${ }^{111}$ the liquidity squeeze in Chinese banks eventually led to a sharp spike in interbank rates offered in June 2013-from below 3\% to a sudden record high of $30 \%$. $^{112}$

Facing these tough economic and financial situations, it is no wonder that the new government has placed the elimination of excess capacity as a top priority on its economic agenda. This task understandably requires measures in multiple fields; but one focal point, as set out by the Chinese government in one of its economic work priorities, is to clear 'zombie companies' in these overproduced industries, so as to

104 'Closing the Zombie Companies! The Central Government Is Concerned with Millions of Unemployment', 31 December 2015, http://www.pcpop.com/doc/1/1595/1595302.shtml.

105 Ibid.

106 Matthew Boesler, 'China is Mass Producing "Zombie Companies" and They are Eating Away at the Economy', Business Insider, 21 August 2012, http://www.businessinsider.com/bofa-china-zombiecompanies-hitting-chinese-economy-2012-8.

107 Zheng (2010), p 666.

108 Statistics suggest that the average annual number of bankruptcy cases in China is less than $0.2 \%$ of that in the US, and the number of SOE bankruptcy cases is almost negligible. 'Why Courts Refuse to Let State-Owned Zombie Enterprises Go Bankrupt?', Phoenix Finance, 28 March 2016, http://finance.ifeng. com/a/20160328/14293875_0.shtml.

109 Du Juan, “'Zombie Companies” Adjust to New Reality', China Daily, 15 March 2016, http://www. chinadaily.com.cn/china/2016twosession/2016-03/15/content_23865916.htm.

110 Sophia Yan, 'Debt-Laden “Zombie” Firms Threaten China's Economy', CNN News, 19 October 2014, http://money.cnn.com/2014/10/19/news/economy/china-corporate-debt/index.html.

111 Fayen Wong, 'China’s Cash Squeeze Caused by Shadow Banking', Reuters, 23 June 2013.

112 Zi Mo, 'Credit Crunch', China Pictorial, 1 August 2008, http://www.chinapictorial.com.cn/en/ industry/txt/2013-08/01/content_558892_2.htm. 
improve efficiency and innovation. ${ }^{113}$ However, this is easier said than done. In addition to the reluctance of various levels of governments to close down zombie SOEs in their own regions, ${ }^{114}$ an unavoidably thorny issue following the reduction of industrial overcapacity would be unemployment-as predicted, in the coal and steel industries alone at least 1.8 million workers will have to be laid off, which could trigger severe social instability if not tackled properly. ${ }^{115}$ At its worst, it could even threaten the legitimacy of the Communist Party-State leadership position. This has been proved by the occurrences of public demonstrations in China-although some have called for human rights improvements, the majority of the demonstrators were primarily motivated by economic concerns. ${ }^{116}$ The latest legal capital reform also emulates the government's eager interest in relieving pressures of unemployment and enhancing social solidity, in the hope that the relaxation of capital provision requirements would be followed by an anticipated increase of employment opportunities, generated from further expansion of private businesses brought about by the reform. ${ }^{117}$ More job opportunities will help with the maintenance of social order and relieve immediate unemployment pressures on the Chinese government following the economic restructuring reform-while reducing zombie companies is important for the sustainable development of the economy, it could also become a source of unrest if unemployment rises exponentially. ${ }^{118}$

\section{A Doctrinal Appraisal of the 2014 Reform}

Commendable legislative objectives notwithstanding, the actual workings of the legal transplants need to be examined from both doctrinal and contextual dimensions. This part, consisting of two sub-parts, devotes itself to the former matter-the doctrinal fit of the transplanted rules to existing legal settings in China and the potential loopholes generating therefrom.

\footnotetext{
113 Lan Lan and Yangpeng Zheng, 'Zombie Companies May Receive Help to Shut Down', China Daily, 7 November 2015, http://www.chinadaily.com.cn/business/2015-11/07/content_22834865.htm. As noted by Liu He, vice-chairman of the National Development and Reform Commission which plays a pivotal role in shepherding China's economic reform agenda, shutting down these unprofitable companies is a necessary step towards market-oriented reform and the upcoming supply-side adjustments. Lan Lan, “"Zombie Companies” Should be Weeded Out', China Daily, 19 October 2015, http://usa.chinadaily.com. cn/epaper/2015-10/19/content_22220063.htm.

114 Lan Lan and Yangpeng Zheng, above n. 113.

115 CCTV, 'China Strives to Ease Employment Pressure while Reducing Excessive Capacity', 1 March 2016, http://english.cntv.cn/2016/03/01/VIDEZU11rJKufjB7k5JmD7Hx160301.shtml.

116 Peerenboom (1993), p 30.

117 The private sector in China has been performing well in terms of job creation-it generated almost all new urban jobs in the past decade, and now employs about four fifths of urban workers. 'The China that Works', 12 September 2015, The Economist, http://www.economist.com/news/leaders/21664143-ifeconomic-miracle-continue-officials-must-give-private-sector-more-freedom.

118 Yojana Sharma, 'What Do You Do with Millions of Extra Graduates?', BBC News, 1 July 2014, http://www.bbc.co.uk/news/business-28062071.
} 


\subsection{Merits of the Reform}

The main doctrinal merit of this latest reform is its diminution of the practice of shareholders illegally taking away their contributed capital, which was a persistent problem before the 2014 reform. Under the 1993 and 2005 legal capital regimes, which were both equipped with statutory minimum capital thresholds, entrepreneurs who intended to benefit from the corporate form and limited liability protection but who were unable or unwilling to meet the stipulated entry bar of incorporation tended to withdraw their contributed amount shortly after their injection of capital and the successful incorporation of the company. Both the 1993 and the 2005 regimes attempted to deal with this deceitful behaviour with a sweeping yet vague prohibition: once a company was registered, its shareholders could not withdraw their capital contributions. ${ }^{119}$ However, nowhere did the Chinese statute map out this provision, for instance, in terms of guidance as to the time frame or the actual behaviour that would be classified as an illegal withdrawal of capital. ${ }^{120}$ All past and present events were therefore scrambled together without regard for their current economic significance. Over the years doctrinal ambiguities have resulted not only in judicial inconsistencies, but also in restrained applications of this prohibitive provision. Case judgments prior to the 2014 reform have suggested that only the most clear-cut behaviour, e.g. an unjustifiable withdrawal of a cash contribution within seven days of capital registration, would be classified as taking away capital illegally. ${ }^{121}$ Meanwhile, other doubtful behaviour with analogous effects of capital shrinkage, such as transferring in-kind contributions to another company's registered place without proper consideration shortly after incorporation, would likely survive judicial challenges. ${ }^{122}$ The 2014 company law reform attempted to solve this problem-it is now possible for entrepreneurs to start a company and enjoy the privileges associated with the corporate form with an initial capital contribution as little as RMB 1, which means that they will generally lose the impulse of injecting and then withdrawing the capital shortly thereafter to get past the minimum threshold prerequisites.

\footnotetext{
119 Company Law 1993, above n. 49, Art. 34.; Company Law 2005, above n. 5, Art. 36.

120 The only document to offer a modest clarification on this matter came seventeen years later, with the Judicial Interpretation III issued by the Supreme People's Court prescribing three specific circumstances of 'illegally taking away capital'. Meanwhile, the time frame of shareholders 'illegally taking away capital' remains unidentified. Zuigao Renmin Fayuan Guanyu Shiyong Zhonghuarenmingongheguo Gongsifa Ruogan Wenti de Guiding San (最高人民法院关于适用《中华人民共和国公司法》若干问题 的规定(三)) [Provisions of the Supreme People's Court on Several Issues concerning the Application of the Company Law of the People's Republic of China (III)] (promulgated by the Supreme People's Court, issued on 27 January 2011, revised and effective on 1 March 2014), Art. 12.

121 E.g. Zhengzhong Su Henan Nianfu Shiye Fazhan Youxiangongsi deng Zhaiquanren Liyi Jiufen An (郑 忠诉河南年富实业发展有限公司等债权人利盆责任纠纷案) [ZhengZhong v. Nianfu Industry Development Co. Ltd] (2014 Heminerchuzi No. 8;(2014) 鹤民二初字第8号) (on file with the authors); Enshi Zizhizhou Hengrong Sujiao Zhipin Youxian Zeren Gongsi deng yu Yu Zuoyuan Gudong Chuzi Jiufen Shangsu An (恩施自治州恒熔塑胶制品有限责任公司等与余作元股东出资纠纷上诉案) [Hengrong Plastic Co. Ltd v. Yu Zuoyuan] (2013 Eenshizhongminzhongzi No. 00662(2013) 鄂恩施中民终字第 00662 号) (on file with the authors).

122 E.g. Hengrong Plastic Co. Ltd v. Yu Zuoyuan (2013), ibid.
} 


\subsection{Doctrinal Defects}

While resolving the issue of shareholders illegally taking away capital, the 2014 reform has brought a few more pragmatic problems, with two particularly standing out, as set out below. The doctrinal incompatibilities and loopholes that follow are partly attributable to the legal transplanting tactics in China-because China's legal borrowing discourse is largely driven by shifts of policy imperatives, it is stopgap and sporadic rather than constituting a set of coherent practices, reflecting the nation's changing policy needs. ${ }^{123}$ As will be explored in Sect. 5, the dominance of this pragmatic approach of selective adoption builds upon Marxist jurisprudence that sees law as a means to State economic and political ends. This instrumental approach in the meantime often leads to the result that only urgently-needed foreign rules in a confined area are transplanted, and then in a fragmented state, leaving some necessary complementarities out of the picture.

\subsubsection{Lack of Strategies to Tackle Dwarf (Empty Shell) Companies with Nominal Share Capital}

The first problem that surfaced following the 2014 reform is the appearance of socalled 'dwarf companies' or 'empty shell companies', namely companies with only a nominal amount of registered capital. ${ }^{124}$ While shareholders in these companies limit their personal liability to the maximum extent, the risks associated with corporate operations are purportedly transferred to creditors under the interest equilibrium discussed in Sect. 2. In practice it is hard for this type of company to get sufficient loan capital for corporate operations, unless the borrowing is ex ante secured by way of shareholders' personal guarantees or security on corporate assets. The issue of unsecured creditor protection thereby stands out: while secured creditors might be able to satisfy their mortgage or other lien interests in assets of the corporate debtor when these dwarf companies go into liquidation, unsecured creditors, most of whom are involuntary in nature, are almost guaranteed a zero return. In the US where minimum capital thresholds have been abolished, there normally exist court-based or statutory prescribed defences for disgruntled creditors, giving courts the ability to subordinate all or part of any secured or unsecured claims of dominant shareholders who sought to shift the risks to other creditors by using nominal share capital. ${ }^{125}$ For instance, the US judiciary first set its face against the loan claims of controlling shareholders as opposed to those of other creditors in an insolvent subsidiary company by way of introducing the

\footnotetext{
${ }^{123}$ The short development period of Chinese law and the lack of experienced draftsmanship also contribute to this type of 'simple and rudimentary' style of legal transplantation. See discussions in Liu (2014), p 34.

${ }^{124}$ Peizhong Gan, 'The Legal Capital Reform Cannot Be One that Leads to More Bubbles', speech at the Application of Company Law Symposium, Beijing, 11 May, 2014, http://www.guancha.cn/ganpeizhong/ 2014_05_16_230053_s.shtml.

125 The equitable subordination doctrine works to this effect. For instance, in the UK categories of deferred debts are normally prescribed by statutes, e.g. the Insolvency Act 1986 s. 74(2)(f). Also, Soden v. British \& Commonwealth Holdings Plc [1998] AC 298.
} 
equitable subordination doctrine. ${ }^{126}$ Likewise, it was the US judicial force which substantially refined the restrictions on share redemptions. ${ }^{127}$ When minded to do so, US judges have made endeavours to acknowledge the substance of a situation rather than be constrained by the narrow formality of the corporate form. However, in China this kind of ex post protective mechanism for creditors is not yet in placenowhere in any existing laws or documents with regulatory effects can one locate a similar provision with the effect of subordinating a dominant shareholder's claim in a situation of competition between himself and a creditor who is not a member of the bankrupt company. Likewise, the broad reach of other areas of law in the US serving to curb practices of hindering, delaying, or defrauding creditors, e.g. the Uniform Fraudulent Transfer Act, ${ }^{128}$ which conveniently fills the gap left by the deregulation in ex ante legal capital, ${ }^{129}$ is also absent in the current Chinese law context, creating further loopholes in involuntary creditor protection. ${ }^{130}$

In light of the doctrinal loopholes mentioned above, the Supreme People's Court (SPC) recently made a novel attempt to introduce the US-originated equitable subordination principle into the Chinese context, by way of issuing a Typical Case and indicating that this principle might be used if helpful. ${ }^{131}$ However, there is reason to be sceptical about the effect of such recourse, after revisiting the nature of the equitable subordination principle and the standing of Typical Cases in China. For a number of years the SPC has been selecting and publishing cases in various fields as supplementary interpretations to the broadly-worded basic laws of China, 'to

\footnotetext{
126 Taylor v. Standard Gas \& Electric Co., 306 US 307 (1939), which has established the equitable subordination doctrine, i.e. the so-called 'Deep Rock Doctrine' working as a defense against the claims of parent companies or other dominant stockholders in bankruptcy and reorganization proceedings.
}

127 E.g. Donahue v. Rodd Electrotype 328 N.E. 2d 505 (Mass 1975), refining the restrictions on selective purchase of shares in a close company context. Essentially, majority shareholders in a close company are not allowed to create a market for their own shares, without extending the same treatment to the minority. In contrast, selective repurchases by a public corporation are generally shielded from judicial review by virtue of the business judgment rule. Bainbridge (2002), p 783.

128 On a different note, fraudulent transfer law in the eyes of US scholars also bears a contractarian nature honouring party autonomy, 'representing one kind of the control that creditors generally would want to impose and that debtors generally would agree to accept'. See Baird and Jackson (1985), p 836. Fraudulent transfer laws have existed in the UK for years, based originally on bankruptcy law.

129 The key purpose of fraudulent transfer law is estate preservation, and the law works to invalidate transactions that have the effect of decreasing the (corporate) debtor's net worth and impairing the rights of its creditors. Liss (1987), pp 1496 and 1499. This is much in line with the main theme of European ex ante capital maintenance mandates, which unfortunately were nowhere to be found in current Chinese company law.

130 A prominent example is the statutory restriction on financial assistance provided to third parties who have acquired company shares. While not grounded on ex ante legal capital mandates, as was the case in Europe, much of the US case law drawing on the Fraudulent Transfer Act has equally recognized that this kind of transfer made to benefit third parties is 'not made for fair consideration'. This sheds important light on correcting corporate creditors' misfortunes, particularly in cases of crafted leveraged buy-outs where corporate assets are indirectly returned to target shareholders by means of 'asset stripping'. Liss (1987), p 1499. See also Credit Managers Ass'n v. Federal Co., 629 F. Supp. 175, 182 (C.D. Cal. 1986); In re Christian and Porter Aluminium Co., 584 F. 2d 326, 337 (9th Cir. 1978); United States v. Gleneagles Inv. Co., 565 F. Supp. 556 (M.D. Pa. 1983).

131 'Shagang Co. v Kaitian Co., published by the Supreme People's Court', 31 March 2015, http://www. court.gov.cn/zixun-xiangqing-14000.html. 
effectively restrain judicial discretion and to ensure the universal application of laws'. ${ }^{132}$ Cases selected and published by the SPC are currently divided into several categories, comprising Guiding Cases, Important Cases, and Typical Cases, none of which have the authority of laws. According to the SPC, only the Guiding Cases present 'guiding effects', i.e. lower courts should make reference to and could quote from these cases when judging cases of the same kind. Meanwhile other types of published cases, including Typical Cases, have 'indicating effect at the most' and cannot be quoted by lower courts. ${ }^{133}$ The fact that the case involving the equitable subordination principle was published as a Typical Case rather than the more forceful Guiding Case indicates the cautious attitude or the tied hands of SPC in terms of introducing this principle.

Furthermore, as famously stated, 'general propositions do not decide concrete cases'. ${ }^{134}$ Even in common law countries, the equitable subordination doctrine is often characterized by issues of an intensely factual nature, and is in need of detailed guidance and elucidation in application. ${ }^{135}$ It was through cumulative judicial applications over the decades that the scope and conditions of this principle gradually became comprehensible, on the basis of the doctrine of stare decisis. ${ }^{136}$ In the meantime, China's civil law system stands at odds with the practice of honouring judicial precedents as established case law, and law-making is viewed as a task for the NPC, the State Council, and various levels of government, rather than for the courts. ${ }^{137}$ It was largely because of this particular concern that an early SPC attempt to introduce the equitable subordination doctrine was thwarted. ${ }^{138}$ Furthermore, the published Typical Case that made reference to the equitable subordination principle loyally follows the conventional style of civil law judgments,

\footnotetext{
132 'Guiding Cases are issued by the SPC', Xinhua Daily Telegraph, June 3 2015, http://news.xinhuanet. com/mrdx/2015-06/03/c_134292583.htm.

${ }^{133}$ Long Bai, 'Zuigaofa Fabu Shoupi Zhidao Anli Zuowei Shenpan Yiju' (最高法发布首批指导案例作 为审判依据) [SPC Issued the First Batch of Guiding Cases for Judicial References], Renmin Daily, 21 December 2012.

${ }^{134}$ Lochner v. New York, 198 US 45 at 76 (1905) (Holmes, J., dissenting).

135 The usage of the equitable subordination doctrine often involves the determination of issues of highly factual nature-for instance, whether or not the plan or transaction which gave rise to a claim carries the earmarks of an arm's length bargain under all circumstances, and whether the corporation was grossly undercapitalized. Pepper v. Litton, 308 US 295 (1939); Costello v. Fazio 256 F.2d 903 (9th cir. 1958). Zhao (2013), p 3.

136 I.e. judicial decisions being both the source and the proof of the law. Dainow (1967), p 425.

137 According to the Legislation Law of the PRC, the National People's Congress (hereinafter the NPC) enacts 'basic laws', the State Council (the head of the executive branch of the government) endorses 'administrative laws', and provincial and sub-provincial governments can issue mandatory 'local regulations' and 'local rules'. Legislation Law of the People's Republic of China, effective from 1 June 2000, Art. 7.

${ }^{138}$ As far back as 2003, the SPC in one of its draft regulatory documents-Provisions on Several Issues concerning the Hearing of Cases involving Corporate Disputes-attempted to introduce the equitable subordination principle by way of Art. 52: in cases where a controlling company abuses the separate personality of its subsidiary company, the controlling company should subordinate its debt claims to other creditors of the subsidiary when the subsidiary company goes into the bankruptcy process. However, the Provisions never entered into force owing to the concern that this factual-based common law doctrine would not fit into the Chinese civil law context.
} 
being abstract and general, with previous cases not cited or analysed. The entire published Typical Case, consisting of background facts, judgments, and the SPC's own interpretations, was less than 1,500 words, with a cautiously brief statement mentioning rather than explaining the equitable subordination doctrine: "while laws in our nation have no comparable provisions, the equitable subordination doctrine established in the US law has certain implications in terms of judging this case'. ${ }^{139}$ There was no interpretation of the factual situations under which the doctrine is applicable, the proper way of subordinating shareholders' claims to other creditors, nor even an explanation of the conception of equitable subordination, regardless of the fact that the provenance and applicability of this doctrine are not without contestation, even in common law jurisdictions with the support of various case precedents. The level of generality at which this equitable subordination doctrine is pitched likely becomes a fertile ground for further disputes and inconsistencies, not to mention the fact that lower courts are not bound to follow the Typical Case. ${ }^{140}$ Without detailed guidance, it is foreseeable that even if the equitable subordination doctrine is to be used by lower courts in China to solve creditor-shareholder conflicts in dwarf companies, judicial inconsistencies would inevitably follow.

Understandably, in the absence of these complementary creditor protection means, Chinese judges rely heavily on the one and major ex post creditor protection means in Chinese company law-the veil-piercing doctrine enshrined in Article 20 (3) of the Company Law. However practice has proved that thus far the application of this doctrine in China has led to suboptimal results. ${ }^{141}$ Firstly, veil-piercing thus far has been selectively applied-it never occurred in State-Owned enterprises, owing to the following reasons: (1) veil-piercing could be ideologically construed as a threat to the dominance of State ownership, which goes against the longestablished Chinese socialist economy ideology; (2) enforcing veil-piercing in SOEs can be thorny, as ownership rights attached to State-owned assets are enforceable only by the State Council, local governments, and State-owned Asset Supervision and Management Commissions. ${ }^{142}$ Secondly, in the private companies' context, veil-piercing applications suffer from inconsistencies and overuse. ${ }^{143}$ While the detailed factual instances under which the veil-piercing remedy might be invoked remain debatable, it is agreed, not only in the West but also among Chinese legislators, that this remedy is an exception rather than the norm, and that it should

\footnotetext{
139 Shagang Co. v. Kaitian Co., published by the Supreme People's Court, 31 March 2015, http://www. court.gov.cn/zixun-xiangqing-14000.html.

${ }^{140}$ Similarly, in a draft commercial case judgment guidance prepared by the SPC in April 2016, there was an article purporting to introduce the equitable subordination doctrine. However, this again merely confirms the applicability of the equitable subordination doctrine in bankrupt companies, without any specific guidance as to its provenance or the conditions triggering its application. See SPC, A Summary of Commercial Case Judgements Conference, 28 April 2016, not yet published and on file with the authors, Art. 5: after a company begins its bankruptcy process, debt claims of the controlling shareholders or other actual controllers of the company should subordinate to claims of other ordinary creditors.

141 Wen (2014).

142 Qiye Guoyou Zichan Guanli Fa (企业国有资产管理法) [Law of the People's Republic of China on the State-Owned Assets of Enterprise] (promulgated by the National People's Congress, 28 October 2008, effective 1 May 2009), Art. 4. See also Wen (2104), pp 334-340 for detailed discussion.
}

143 Wen (2014), pp 345-353. 
be applied with extreme caution, for its potential destruction of the basis of modern company law - the separate legal personality of the corporation. ${ }^{144}$ However, this doctrine has been practically applied as a panacea rather than an exception in almost all the conflicts between shareholder and creditor, despite the fact that some clearly do not fall into the scope of Article 20(3) of the Company Law. ${ }^{145}$ Furthermore, in cases concerning capital provision in dwarf companies, the application of this doctrine would not provide effective redress to unsecured creditors under the current Chinese law-SPC limits the liability of shareholders who fail to pay in capital to the amount they have failed to pay into the company, ${ }^{146}$ even though this type of case was invariably treated by Chinese courts as abuse by shareholders of the corporate form and Article 20 was triggered. ${ }^{147}$ Thus, in the context of dwarf companies with a small amount of registered capital, the compensation unsecured creditors could obtain from shareholders would be nominal under existing legal settings, even based upon successful veil-piercings.

\subsubsection{Problems Surrounding Scoundrel Companies with Enormous Unpaid Share Capital}

If the growth of dwarf companies can still be interpreted as an inevitable consequence following the removal of minimum capital thresholds and the encouragement of private entrepreneurship, new pragmatic problems now surfacing in China associated with enormous amounts of unpaid share capital are largely caused by the defective doctrinal details of the 2014 amendments. One rhetoric underpinning this legal capital reform is to create an operating environment where companies can 'register easily but operate under strict supervision'. ${ }^{148}$ While the registration process has now become a lot more user-friendly, the expected 'strict supervision' over capital contribution and maintenance largely remains rhetorical: the right of determining the value of in-kind capital contributions and the obligation

\footnotetext{
144 As stated by Min Liu, a judge sitting on the SPC, 'between the separate legal personality doctrine and the piercing doctrine, the former undoubtedly presides. What merits special attention in judicial practice is that we cannot easily refute the limited liability of shareholders in the name of creditor protection. Simply put, we cannot overuse the doctrine of piercing the veil'. See Min Liu, 'Faren Renge Fouren Zhidu zai Ge'an zhong de Shenzhong Shiyong' (法人人格否认制度在个案中的慎重适用) [A Cautious Application of the Veil-Piercing Doctrine], Guidance and Reference to Civil and Commercial Judgements in China 1 (2005), http://www.civillaw.com.cn/article/default.asp?id=29016.

145 The overall rate of veil-piercing in China has so far been significantly higher than in other countries, and the number is still rising annually. Huang (2012), p 3. See also Wen (2014), pp 343-344, for examples of misapplications of veil-piercing.

146 Arts. 13 and 14 of the Third Regulation of the SPC on Several Issues in the Application of the PRC Company Law, promulgated by the SPC on 6 December, 2010. The SPC might impose this limit on the basis that the unpaid capital amounts as outstanding amounts due on the shares. However, this limit purportedly contradicts the ideal of veil-piercing, under which shareholders undertake unlimited liability. In other situations where Chinese courts have applied Art. 20, such as the commingling of shareholder and corporate funds, no such cap has been placed on shareholder liability. Hawes et al. (2015), p 10.

147 See the empirical study conducted by Hawes et al. (2015), p 8.

148 Moxiao Tan and Jun Dong, 'The Facilitation of Corporate Registration Requires Governments to Enhance Supervision', Xinhua Net, 23 September 2014, http://finance.china.com.cn/news/gnjj/20140923/ 2693037.shtml.
} 
of checking the authenticity of capital contributions are left completely to the board, who often submit to the will of shareholders. ${ }^{149}$ Information asymmetry further prevents outside stakeholders, particularly creditors who are affected the most by this legislative change, from overseeing boards' decision-making and corporate operations in China. After the 2014 legislative change, detailed information in relation to capital contribution, including the unpaid amount of share capital, the amount to be paid up at the time of registration, and the required time period for each shareholder to pay up his subscribed capital, is no longer required to be recorded on the business license, ${ }^{150}$ which is often the only official document that unsecured creditors can have access to. Although these capital contribution details are recorded on the Articles of Incorporation, in current practice the Articles of registered companies are kept at local Industrial and Commercial Bureaus and are only available to those who have the company's written permission, or to lawyers who act for that particular company. For outside creditors who wish to challenge the arrangements and practices of capital contribution, accessing the Articles is pragmatically difficult, if not impossible.

In relation to realizing the State Administration for Industry and Commerce's (SAIC) pledge of 'easing market entries whilst reinforcing governance (of firms)' and eliminating information asymmetry between internal corporate controllers and outside creditors, an Enterprise Credit Management Information System was recently set up to provide various stakeholders with more clarity and better access to information relevant to the company. ${ }^{151}$ However, the actual effect of this system is doubtful to say the least. The information recorded on the Credit Management System is categorized into Registration Information, which is required by Industry and Commerce authorities; and Public Information, which is disclosed purely at enterprises' discretion. ${ }^{152}$ Most essential financial information, such as the total assets and liabilities of the company, total sales, and shareholders' equity, is within the realm of Public Information and thus is disclosed at the enterprises' discretion. In current practice the only Registration Information disclosed on the system concerning legal capital is the amount of registered capital and the names of shareholders, the same as the information recorded on the business license. ${ }^{153}$ Other essential information, including the amount of actual injected capital, the paying-up period, and details of each shareholder's capital subscription and actual capital

\footnotetext{
149 Company Law 2005, above n. 5, Art. 29, now removed by Company Law 2013.

150 Company Law 2013, above n. 5, Art. 7.

151 See http://gsxt.saic.gov.cn/ for further details. The operation of this system is governed by Qiye Xinxi Gongshi Zanxing Tiaoli [Temporary Rules for Public Disclosure of Information by Enterprises], State Council Order No. 654, effective from 1 October 2014. The Chinese version is available at http://www. gov.cn/zhengce/2014-08/23/content_2739774.htm.

152 Qiye Xinxi Gongshi Zanxing Tiaoli (企业信息公示暂行条例) [Temporary Rules for Public Disclosure of Information by Enterprises], ibid., Art. 9.

153 In the current Credit Management System, it is stated in the column for 'shareholder information' that 'information relevant to shareholders' capital contribution is updated until 28 February, 2014. Afterwards the Industry and Commerce authorities only disclose the names of shareholders. All other information is disclosed at the enterprises' discretion.' See http://gsxt.saic.gov.cn/ for further details. Accessed 15 January, 2017.
} 
injection, is disclosed in the form of businesses' annual reports, and authorities will only choose a small amount of sample companies to check the authenticity of such information. ${ }^{154}$ To make things more complicated, the responsibilities for checking the authenticity of information and penalizing those who fail to make the required disclosures are confusingly spread among several government organs at various levels, whose scopes of authority obscuringly overlap. ${ }^{155}$ The methods and scope of such random checks also remain undefined, leaving considerable gaps in implementation. ${ }^{156}$ This has provided new loopholes for the manipulation of fraudsters, as evidenced by the notorious investment company fraud case that occurred in the city of Changchun in 2015. ${ }^{157}$ A number of fraudsters lawfully registered eighteen investment companies to engage in P2P financing business, each with RMB 30 million or RMB 50 million registered capital, but RMB 0 paid-up capital at the time of registration. As the business licenses and the Enterprise Credit Management Information System available to the public only showed the amount of registered capital in these companies, which at face value seemed financially competent, the fraudsters managed to borrow nearly RMB 100 million from hundreds of investors before their escape, resulting in huge losses for investors and widely adverse social impacts. ${ }^{158}$

Apart from the increase of fraudulent activities, the upsurge of so-called Scoundrel Companies, i.e. companies featuring a high amount of registered capital, nearly nil paid-up capital at the time of registration, and an extremely long subscription period, ${ }^{159}$ have also become a common phenomenon after the 2014 legal capital reform. The undercapitalization status of these companies has brought difficulties not only to creditors, but also to shareholders of the companies. Under China's current corporate and bankruptcy laws, if a company with unpaid share capital cannot satisfy creditors' debt claims and the unpaid share capital is not yet due, creditors do not have direct legal recourse against the particular shareholder whose subscribed capital is not yet due, but need to first apply to the court for the bankruptcy of the company, and then the liquidator must demand the particular shareholder to fulfil the capital provision obligation despite the subscription period provision in the Articles. ${ }^{160}$ Needless to say, it is a lengthy

154 Qiye Xinxi Gongshi Zanxing Tiaoli (企业信息公示暂行条例) [Temporary Rules for Public Disclosure of Information by Enterprises], State Council Order No. 654, effective from 1 October 2014, Arts. 14-15.

155 See Qiye Xinxi Gongshi Zanxing Tiaoli (企业信息公示暂行条例) [Temporary Rules for Public Disclosure of Information by Enterprises], ibid., Arts. 5-8.

$156 \mathrm{Xu}$ (2015), p 24.

157 Wu Hao, Hanqi Meng, '18 Investment Companies Gathered Money and Ran Away: Whom Did the ORMB Companies Trick?', China Daily, 2 July 2015, http://www.chinadaily.com.cn/micro-reading/dzh/ 2015-07-02/content_13914834.html.

158 Ibid.

159 Peizhong Gan, 'The Legal Capital Reform Cannot Be One that Leads to More Bubbles', speech at the Application of Company Law Symposium, Beijing, 11 May 2014, http://www.guancha.cn/ganpeizhong/ 2014_05_16_230053_s.shtml.

160 Enterprise Bankruptcy Law of the People's Republic of China, adopted at the 23rd meeting of the Standing Committee of the 10th National People's Congress of the People's Republic of China on 27 August 2006, promulgated and coming into force as of 1 June 2007, Art. 5. 
and difficult process for creditors of the company to eventually get their claims fulfilled, if they ever do. ${ }^{161}$

It would not be fair to say that the difficulties that corporate creditors face after the 2014 reform have gone completely unnoticed. In the recently drafted Commercial Case Judgement Guidance prepared by the SPC, the undercapitalization status of the company was singled out in Article 6 to be tackled by courts via piercing the corporate veil and asking the shareholder to bear joint liability with the company. As stipulated in Article 6:

If the capital subscription period provided in the Articles of Association is notably long, or the actual injected capital of the company is notably incompatible with the operation scale and risks of the corporation, corporate creditors' veil-piercing claims on the basis of Art. 20(3) of the Company Law should be supported. ${ }^{162}$

However, this proposed approach contradicts the well-accepted legislative and judicial reiteration of the separate legal personality of corporations, as discussed above. ${ }^{163}$ If Article 6 were to be put into implementation, an unwarranted effect would be shareholders in all dwarf companies with a nominal amount of registered capital being exposed to the risk of unlimited personal liabilities, as this type of company, save for those not engaging in actual business, neatly fits the description of actual capital being incompatible with their operational risks.

Additional to the difficulties for creditors, the huge discrepancy between registered capital and actual injected capital in scoundrel companies has also generated new types of legal disputes between shareholders, as shown in two recent cases in Guangdong province. ${ }^{164}$ The defendants in both cases agreed to subscribe for more than $60 \%$ of the share capital, payable within five years of registration, as provided in the Articles of Incorporation. Registered in mid-2014 after the promulgation of new legal capital provisions, both companies had actually received $\mathrm{RMB} 0$ injected capital from the defendant shareholders at the time of registration. The claimants of both cases, being shareholders of the concerned companies who had already made their respective capital contribution, sought for the defendants to expedite their share capital contribution, claiming that their companies experienced serious financial difficulties and could not run properly owing to the undercapitalized status caused by the defendants' noncontributions. Both claims were rejected by the courts on the basis of party autonomy-as the subscription periods stipulated in the Articles were not yet due, both defendants' non-contribution behaviour, although causing serious distress for corporate operations and other shareholders, was nonetheless lawful under Chinese company law. If the shareholders wished to resolve the situation, the only option

\footnotetext{
161 Peizhong Gan, above n. 159.

162 SPC, A Summary of Commercial Case Judgements Conference, above n. 140.

163 Above n. 144 and relevant texts.

164 Ruan Jiahao v. Chen Weiguo, 阮嘉豪诉陈卫国股东出资纠纷案, (2015) 珠香法民二初字第 285 号, (2015) Zhuxiangfamin'erchuzi No. 285; Baohe Furniture Co. Ltd v. Liu Saiya 东莞市葆和家具有限公司 诉刘赛亚股东出资纠纷案 (2015) 东二法民二初字第 171号 (2015) Dong'erfamin'erchuzi No. 171.
} 
for them under the current Chinese law regime would be to apply for the dissolution of the company, ${ }^{165}$ which would completely thwart the purpose of their investment. Furthermore, even in these two similar cases judged by courts in the same province, there is inconsistency. It was stated in the Ruan Jiahao Case judgement that if the claimant shareholders had proved that the company was indeed in financial difficulties caused by the defendants' behaviour, the claim would have been supported. However, the judgment of the Baohe case reached a completely different conclusion, stating that proofs of the financial difficulties of the company and the causation link were irrelevant to the claim. This hints at mounting judicial confusion in the field, owing to the lack of authoritative and detailed guidance.

\section{The Soil in Which the 2014 Transplants Take Root-Socio-Cultural Embeddings and Implications}

As suggested by Robert Cover, '(an appreciation of law should not be) merely a system of rules to be observed, but a world in which we live'. ${ }^{166}$ As shown by the national-specific agendas of legal capital reforms in China and their fit with existing doctrinal settings, transplanted rules are more than mere inscribed words from another jurisdiction, functioning as part of a new and larger cognitive framework containing different idiosyncratic constructions.

Taking root in different socio-cultural soil, the actual workings of legal transplants are also constitutive of the host country's articulated values. After all, it is easy to borrow rules, but it is difficult to transplant the history and the frameworks of the intangibles behind the rules which gave birth to the inscribed words. ${ }^{167}$ Viewed on an ideological spectrum, the debate about whether to utilize capital provision mandates also consists of one strand of the larger State-meets-market dialogue, which is endemic to the political economy of nations and corporations. ${ }^{168}$ Even in the postCold War period today, different socio-political embeddings still impact on the process and actual effects of the capital provision reforms, underlining the longlasting socio-cultural contrasts between the US and China. These socio-cultural differences between host and home contexts in turn watered down the anticipated functionality of the 2014 reform, particularly boosting the private economy and injecting liberal market values, as will be presented in the following sections.

\subsection{West (The US Orbit)}

From the conceptual perspective, relaxing legal capital rules chimes with the mainstream rule of law rhetoric in the US context, emphasizing both the constraining effect of law on the State's capacity and the discrete role of law in

\footnotetext{
165 Company Law 2013, above n. 5, Art. 182.

166 Cover (1983), pp 4, 5.

167 Clarke (2006), p 14.

168 Levi-Faur (1997).
} 
empowering private economic actors. ${ }^{169}$ Founded on Locke's postulation of humans as liberal beings with a natural right to defend 'life, health, liberty or possessions ${ }^{170}$ rather than affiliations of a State, the sanctity of individuals' inherent rights has long been honoured, and duties have often been presented as corollaries to rights. ${ }^{171}$ Indeed, a cursory look would discover that this rule of law conception based on individual rights was echoed in many aspects of the American world. It was reflected 'in the political rhetoric of the "founding fathers" of the United States', ${ }^{172}$ it prompted the inauguration of the American Declaration of Independence; ${ }^{173}$ it resulted in the Constitutional divide of State power, ${ }^{174}$ and it also impacted on the general common law tendency to give greater emphasis to the rights of the parties than to State interests. ${ }^{175}$

Central to this rule of law notion is an autonomous pre-existing order of contract and property prescription, to prevent undue expropriation by the State. ${ }^{176}$ Echoing the views of economists that 'whatever the State does, it should provide effective institutions and processes to protect private property rights and enforce contracts, which are considered prerequisites for investment and economic growth in market economies', ${ }^{177}$ while there had been heated intellectual debates in the legal profession about the balance between regulation and market logic in the nation's history, ${ }^{178}$ the general attitude of the US RMBCA, particularly after the 1970s, has not anticipated a large State presence in the enterprises it regulates. ${ }^{179}$ The fact that company and commercial law creation and reform in the US are often pushed by private groups' lobbying efforts also to a large extent exemplifies this overriding principle of party autonomy, evidenced in the rhetoric of 'meeting the needs of business practice', ${ }^{180}$ such as abolishing minimum capital thresholds and other restraints on corporate capital.

\footnotetext{
169 Ginsburg (2000), p 832.

170 Locke (1690), Chapter II, Sect. 6. Many consider that Locke's theory of rights inspired the founding of the United States, particularly the inauguration of the American Declaration of Independence. E.g. Zuckert (1996), pp 73-85.

171 Peerenboom (1993), pp 39-43.

172 Orts (2001), p 88.

173 Redish and Cisar (1991), p 456.

174 The constitutional limitation of federal legislative power to the Congress has been confirmed and applied in FCC v. RCA Communications, Inc., 346 US 86, 90 (1953); Cooper v. Aaron, 358 US 1, 16-17 (1958); McFarland v. American Sugar Co., 241 US 79, 86-87 (1916) (Holmes, J.); Orts (2001), p 88.

175 Hartley (2009), p 344.

176 Lan (2014), p 385; Ginsburg (2000), p 833.

177 Prado and Trebilcock (2009), p 345; research also suggests that countries effectively protecting property rights and resolving contractual disputes tend to have a more transparent and facilitative environment in which capitalism can flourish. North (1991), pp 477-487.

178 See Purcell Jr (1969), pp 424-446 for a detailed examination of the trajectory of the intellectual debate surrounding the subject of law in the US.

179 Clarke (2006), p 19.

180 Ramsay (2001), pp 566-567.
} 


\subsection{East (China)}

In stark contrast to the sanctity of party autonomy and the rule of law notion underpinning the US orbit, the making and unmaking of capital provision rules in China has had a strong instrumental and command character, functioning as part and parcel of the State-led socio-economic reforms detailed in Sect. 3. As China's policies shift towards establishing a market economy, instead of being marginalized as advocated by liberal theories, ${ }^{181}$ law as a tool of the State is becoming more important. The State structures and leads the process of growth, channels capital, and guides the activities of private actors via laws, with the purpose of establishing a socialist market economy with Chinese characteristics.

Though the instrumental and relativistic nature of the law spreading throughout most of Chinese intellectual life bears certain similarities to Western realists' conception of law as 'an engine having purposes, not values in itself', ${ }^{182}$ one must acknowledge that the Chinese instrumental view of law grows out of its own pedigree and jurisprudential logic, as will be examined in the sections to follow. Furthermore, the mainstream State-central view in China has never been commonly held in the US ambit because of the possibility of it turning into 'a ruthless totalitarianism' ${ }^{183}$ Under a different orientation of law towards the State rather than private ordering, the borrowed RMBCA configurations concerning capital provision have understandably been contextualized in China, generating further practical consequences unique to the Chinese context, which will be explored in Sect. 6.

\subsubsection{Cultural Tradition: The Collective Nature of Confucianism}

Prevailing within a continuous civilization for more than two thousand years, ${ }^{184}$ the long-dominating Confucianism has had a strong effect in shaping China's legal traditions and jurisprudential thoughts. Through the lens of Confucianism, each individual is an essential unit in multi-lateral social guanxi $^{185}$ webs, with a pre-set

\footnotetext{
181 Ginsburg (2000), p 836.

182 Llewellyn (1930), p 464. The Chinese instrumental view of law differs from the thinking of Western realists, in the sense that the Chinese view does not tend to reduce law to specific judicial decisions. Purcell (1969), p 431.

183 Purcell (1969), p 439.

184 Jensen (1997), p 4.

185 Guanxi means personal connections or relationships, and renqing means reciprocity. Guanxi is a central life philosophy for many aspects of Chinese life. The Chinese have turned the art of personal relationships into a carefully calculated science, and there are people whose lives rely heavily upon guanxi. There are arguable benefits of building an extensive guanxi network, such as reducing transaction costs, operational uncertainty, information costs, contextual hazards and competitive threats. Other benefits include enhancing institutional support, economic returns, business effectiveness, organizational legitimacy, and strategic capability, in order to provide more efficient mechanisms for transactions by acting as the catalyst for the development of new market channels and investment opportunities. See MeiHui Yang (2002); Zhao and Wen (2013), p 381.
} 
hierarchical position and various societal duties to fulfil, ${ }^{186}$ rather than an isolated being to whom ahistorical, universal rights may attach. Grand social harmony, in a Confucian view, should be mainly attained via the establishment and maintenance of stable relationships among individuals, by way of cultivating people with core moralities and ethical propriety. ${ }^{187}$ While Confucianism does not overlook the governing impact of law, law is viewed as an instrument inferior to the above stated system of ethics, as law 'could only discipline the evil, but not encourage the virtuous'. ${ }^{188}$ Confucians believe that the basis of a stable, unified and long-term social order is maintained through living according to civilized and cultured principles that are generated through human wisdoms rather than the imposition of strict law on individuals. ${ }^{189}$ Most importantly, in support of the social hierarchical order, law was viewed by Confucianists as a tool used by the Emperor and aristocrats to secure their power over the ordinary people and confer on themselves special privileges, such that they couldn't be arrested by judicial departments without the Emperor's special permission. ${ }^{190}$ The paternalism in Confucian values indicates that the state has the knowledge necessary to rule the people, and will act for the interests of the people. ${ }^{191}$ Therefore, a system of centralized hierarchical governance was founded, ${ }^{192}$ and the well-known saying that 'punishments are not designed for the elites, and rights do not extend to ordinary people' ${ }^{193}$ is a typical illustration of this hierarchical regime.

The long-standing dominance of Confucianism has dictated and continues to impact on the uniqueness of modern Chinese legislative thought in three aspects. The first of these is Chinese law's emphasis on a person's duties within a social hierarchy, which is different to the US accentuation of the independence of individuals and their intrinsic rights which stem 'from the inherent dignity of the human person', ${ }^{194}$ as discussed in the section above. With a well-established hierarchical system of governance and elaborate bureaucracies for drafting and enforcing various legislations, the culture of worshipping authority has been deeply

\footnotetext{
186 Yeung and Tung (1996), p 55.

187 Huang (1999), pp 9-10; Keung Ip (2009), p 464.

188 'Fu Falingzhe Suoyi Zhu'e, Fei Suoyi Quanshan' (夫法令者所以诛恶, 非所以劝善) Lujia, 'A Discussion of Salt and Iron, Volume 10 (恒宽[盐铁论]卷十)', quoted in Qu (2003), p 310.

189 Miles (2006), pp 305-306.

190 Such special privileges were available in many dynasties, beginning from the Han Dynasty and extending throughout the Tang and Song Dynasties. Qu (2003), pp 225-235.

191 Hamilton (1990).

192 Haley (2006).

193 'Li Buxia Shuren, Xing Bushang Dafu' (礼不下庶人, 刑不上大夫). The Book of Rights (礼记·曲礼 上), http://www.guoxue123.com/jinbu/ssj/lj/003.htm.

194 International Covenant on Civil and Political Rights (adopted and opened for signature, ratification and accession by General Assembly resolution 2200A (XXI) of 16 December 1966, entry into force 23 March 1976, in accordance with Art. 49), 1.
} 
rooted. ${ }^{195}$ Second, the emphasis on human relationships cultivates mutual obligations and values in society, and in some aspects functions as a relation-based governance system, as a substitute for the authority of written laws in China. ${ }^{196}$ Even today, the idea that 'law is no more than human interactions' ${ }^{197}$ is still widely held in Chinese society, indicating the persistence of Confucian collectivism. Third, people are familiar with the instrumental idea of law being a governing tool of the State, rather than the US rule of law rhetoric that emphasizes the restraining effect of law on the State. The hierarchy of the Party-State over individuals is still maintained on many fronts, and formally consolidated in Article 51 of the current Constitution. ${ }^{198}$

After the new generation of leadership took power in 2013, President Xi and other leaders began to pivot back to Confucian and other classical Chinese philosophies in state governance and law, formally emphasising that the rule of law must be combined with the rule of virtue, and that socialist legal norms must integrate with traditional Chinese virtues. ${ }^{199}$ This helps to tactically justify the supremacy of the Party amid China's cultural specific context and the authoritative interpretation of law, functioning as 'a revised authoritarian party apparatus dressed up in Confucian garb'. ${ }^{200}$ It also impinges on China's own interpretation of the notion of the rule of law, which emphasizes the 'formal or instrumental aspects' of law, ${ }^{201}$ particularly the availability of predictable and performable rules. This is in contrast with the wider understanding of the rule of law prevailing in the West, which connects primarily to the American pattern of liberal democracy underpinned by the tripartite division of power restraining governmental powers.

\subsubsection{Political Ideology: The Chinese Development of Marxism}

The instrumental vision of law in China as an axiom rather than a school of thought is also in line with the primary Chinese ideology of Marxism - a philosophy that has long been discredited in the US. Central to Marxist theory is the idea of economic determinism, describing the correlation between the material 'base' and the

\footnotetext{
195 Wang et al. (2012), pp 350 and 368.

196 White (2006), p 29.

197 I.e. 'Falv Buwaihu Renqing' (法律不外乎人情) [Law Is No More Than Human Interactions], Foshan Daily, 6 November 2013.

198 Constitution of the People's Republic of China, amended in accordance with the Amendments to the Constitution of the People's Republic of China adopted respectively at the First Session of the Seventh National People's Congress on 12 April 1988, the First Session of the Eighth National People's Congress on 29 March 1993, the Second Session of the Ninth National People's Congress on 15 March 1999 and the Second Session of the Tenth National People's Congress on 14 March 2004), [Constitution] Art. 51. 199 'Xi Stresses Integrating Law, Virtue in State Governance', Xinhua Net, 10 December 2016, http:// news.xinhuanet.com/english/2016-12/10/c_135895641.htm. The concept of Dezhi (in Chinese) or rule of virtue clearly is a Confucian inspirational idea, emphasising that 'all legal systems involve both ren zhi (rule of man) and fa zhi (rule of law)'. Peerenboom (2015), p 60.

${ }^{200}$ Carl Minzner, 'How China's Leaders Will Rule on the Law', China File, 15 October 2014, http:// www.chinafile.com/reporting-opinion/viewpoint/how-chinas-leaders-will-rule-law.

${ }^{201}$ Peerenboom (2002), pp 471-473.
} 
ideological structure of a society that embraces all political, legal, and cultural institutions. ${ }^{202}$ Contemporary China developed this economic determinism of law, stating that the foremost human right is the right to subsistence, which could only be achieved under the leadership of the Party-the vanguard of the Chinese working class, the Chinese people, and the Chinese nation. ${ }^{203}$ For Chinese scholars, the prime position of the Party-State in law, as well as the instrumental character of law in pursuing economic policies, are justified by and echo the Marxist spirit of law. Although the State and laws will eventually 'wither away' with the realization of a communist society, during the current period of socialism, laws and legal institutions are necessary in China to achieve social solidarity and promote the economic and political imperatives of the Party-State. ${ }^{204}$ A defining hallmark of the Chinese mode of governance has thus been its overriding Party-State control over key economic sectors ${ }^{205}$-or, in the words of Breslin, 'a State-led engagement with globalization'. ${ }^{206}$ Though a separation of enterprise and administration has been advocated at the corporate level, the Chinese government still consistently intervenes in major aspects of the economy using macroeconomic policy toolsfor instance, the Central Government utilizing Five-Year Plans to screen major State enterprise investments and closely monitoring the situation in every industrial activity. $^{207}$ The first and foremost policy priority outlined in China's latest FiveYear Plan is again 'reinforcing and enhancing Party leadership and government macro-control'. ${ }^{208}$ In the process of deepening China's market economy and intensifying market competition, the government will act as the main facilitator of economic development and adjust the market so that it can direct the route of transformation. $^{209}$ The government also plays various roles in business

\footnotetext{
202 Wacks (2012), p 179.

203 Information Office of the State Council of the People's Republic of China, Human Rights in ChinaWhite Paper (1991), Chapter I; Constitution of Communist Party of China, revised and adopted at the 18th National Congress of the Communist Party of China on 14 November, 2012. English text of the Constitution is available at http://english.cpc.people.com.cn/206972/206981/8188065.html. Although in form the Party and State systems are separate - each has its own constitution, institutions, and rules-in practice and ideology the Party and State are combined together by socio-political theories justifying the supremacy of the Party, such that the Party 'represents advanced social productive forces (economically), the progressive course of China's advanced culture (cultural development), and the fundamental interests of the Chinese people (political consensus)'. Further details are available at http://english.cpc.people.com. cn/66739/4521344.html.

204 'Shehuizhuyi Chujijieduan Zhuyao Maodun' (社会主义初级阶段主要矛盾) [The Main Conflicts in the Initial Stage of Socialism], http://dangshi.people.com.cn/GB/165617/173273/10357187.html. Also Orts (2001), p 106.

205 'There is disagreement over what the key ingredients of this (China) model might be, but a managed exchange rate, state control over key industries including the banking system, preference for diktat rather than democratic debate, heavy state investment in infrastructure and strong support for the export sector are variously mentioned.' 'China Model', Economist, http://www.economist.com/debate/overview/179; also Peerenboom (1993), p 53.

206 Breslin (2011), p 1329.

207 Kennedy (2010), p 471.

208 China's Five-Year Plan, Chapter 1.2 Guiding Thoughts, the Chinese version is available at http:// www.china.com.cn/policy/txt/2011-03/16/content_22156007.htm.

209 Chen (2014).
} 
developments, e.g. as a regulator in overseeing markets, as a supervisor and promoter of business activities, as well as having a role in the adaptation and utilization of international rules on corporate governance. Targeted governmental control on economic growth will be given even greater importance as the macrocontrol ideology of this new generation of government, according to Premier Li. ${ }^{210}$

\subsubsection{Impacts of Cultural and Ideological Factors on Capital Provision Reforms}

As commented by Orts, law in China 'presents a mosaic of traditional legal conceptions, the strong historical influences [...] and Marxist theory, and strenuous current efforts to adapt to the legal requirements of a fast-changing global economy'. ${ }^{211}$ The ideological and cultural elements specified above have impacted on both the substance and processes of China's sequential attempts at transplanting Western pro-market legal capital configurations. To begin with, as clearly elucidated in the Official Notice of Reform, introducing the 2014 legal capital regime was a 'major decision made by the Party and the State Council', reflecting the gist of 'the 2nd and 3rd Plenary Sessions of the 18th Central Committee of the CPC'. ${ }^{212}$ Furthermore, the substance of this legal capital reform is cautiously placed within the ideological confines of the so-called 'socialist market-based economic reform, ${ }^{213}$ and by no means challenges the sanctity of the Party-State authoritarian regime in China. To secure the basic tenet of the current Party-State-led socialism, ${ }^{214}$ private economic sectors and free markets, which used to be seen as signs of capitalism, were first ideologically legitimized in the transplantation process, by way of the Constitutional stipulation of their necessity in the current socialist regime. ${ }^{215}$ The degree of transplanting foreign rules is also cautiously confined, by stipulating that all sorts of private economic sector should develop to complement public ownership, which plays 'a dominant role' in the current economic regime in China. ${ }^{216}$ The supremacy of SOEs also remains after the legal capital reform, both in their overall economic strength and the occupation of strategically important sectors, as this is inevitably linked to the Party and the government's legitimacy. A cursory look at the 2015 China Top 500 Enterprises list suggests that SOEs account for $80 \%$ of the revenues and nearly $90 \%$ of the tax contributions. $^{217}$ Of the one hundred Chinese companies on the 2014 Fortune

\footnotetext{
210 'China Stresses 'Targeted' Economic Control', 10 June 2014, http://english.gov.cn/photos/2014/08/ 23/content_281474983011916.html.

211 Orts (2001), p 43, at pp 71-72.

212 The State Council, 'Zhuce Ziben Dengji Zhidu Gaige Fang'an' (注册资本登记制度改革方案) [Subscribed Capital Registration Regime Reform Plan], Guofa [2014] No. 7, 7 February 2014.

213 Ibid., Guiding Thoughts.

214 Peerenboom (2010b), p 91.

215 The Constitution of the Chinese Communist Party (revised on 14 Novmber 2012), General Programme, para. 9, http://www.china.org.cn/chinese/18da/2012-11/19/content_27156212_2.htm.

216 Ibid.

217 'China Issues Guideline to Deepen SOE Reforms', CCTV News, 13 September 2015. http://english. cntv.cn/2015/09/13/VIDE1442158197379963.shtml.
} 
Global 500 list, ninety-two are state-owned. ${ }^{218}$ 'SOEs should not be weakened, but should be strengthened'. ${ }^{219}$ This latest remark from President Jingping Xi not only epitomizes the overall socio-economic policy tone of the new generation of government, but also unveils another round of SOE reform, in the hope of stimulating the vigour of this dominant economic force, put forward in the recent Communiqué of the Third Plenary Session of the 18th Central Committee of the CPC as discussed in Sect. 3. The fact that the 2014 legal capital reform serves the purpose of reducing the side-effects of eliminating zombie SOEs best epitomizes the dominating position of SOEs in the foreseeable future. This is in stark contrast to the legislative vision and practice in the US ambit, where the capital provision configurations support a less interventionist administrative regime that constrains rather than empowers governments. ${ }^{220}$

The instrumental maxim of the law as a governing tool of the State, and the Party-State's dominance echoing the Marxist spirit of law, also manifest in the process of the latest legal capital reform. According to the Legislation Law of the PRC, the National People's Congress (NPC) - the supreme legislative organ 'through which the people exercise state power' 221 _enacts and revises 'basic laws' such as Company Law, and the State Council is supposedly responsible for the enactment and revision of 'administrative laws' only. ${ }^{222}$ However, from the initial reform proposal being put forward up to the final bill receiving NPC approval, the 2014 reform was entirely top-down and dominated by the State Council (the head of the executive branch of the government), with limited input from non-governmental actors or the public. The reform plan was first unveiled on 27 October 2013 by the state media Xinhua News Agency, citing the speech made by Premier Keqiang Li at the State Council executive meeting on 25 October $2013 .^{223}$ The grand reform plan for company law was discussed and announced at the aforementioned meeting of the State Council, absent any previous scholarly discussions or public consultations. This premature public disclosure also placed considerable pressures on other political authorities to pass the reform plan swiftly, almost as a knee-jerk reactionthe entire reforming plan concerning legal capital put forward by the State Council was officially approved by the Party-State half a month later in the Central Committee of the Communist Party's Third Plenum in November, and then all detailed company law revisions approved by the NPC in December 2013, without revision, less than two months later. Legal scholars and the public were not given adequate time or opportunities to offer input to the making of these new legal capital rules, either in the process of drafting or at the reviewing and passage stages. Local Republic of China] (promulgated by the President of the People's Republic of China, 15 March 2000, effective 1 July 2000), Art. 7.

223 http://finance.sina.com.cn/china/20131027/160117127254.shtml; see also Jiang (2014).
} 
testing of the proposed reform was also carried out in a hasty mannerexperimentation was only initiated in two pilot cities, Shenzhen and Zhuhai, in March 2013, offering a limited test run of less than six months' duration before this important reform of law came to fruition ${ }^{224}$; followed by another experiment launched in Shanghai in September, ${ }^{225}$ just one month prior to the launch of the reform plan. The short duration of these pilot schemes rendered it impossible for scholars and the public to fully examine the feasibility of the planned reform, and to make bottom-up innovation contributions as envisaged. ${ }^{226}$ It is thus no wonder that in scholarly words, this legislative amendment was described as 'forced' by the State Council, ${ }^{227}$ with them being given no option other than 'passive acceptance' of the entire reform plan. ${ }^{228}$

Although one major purpose of the 2014 reform, as discussed in Sect. 3, is to reduce administrative control and to give full play to the basic role of the market in resource allocation and efficiency creation, the process and substance of the legislative reform continue to evidence the strong force of administrative orders. While the transplanted rules follow the US RMBCA in form, the ignorance or downplaying of the tremendous institutional variations has made the reform largely a gesture by which the Chinese government has tried to reduce governmental control and inject liberal market values. The case of legal capital reform is thus a prime example attesting to the impact of socio-cultural factors in shaping China's legislative reforms, and to Montesquieu's statement that imported law owes its very existence to its fit to local conditions.

\section{Further Irritants Impeding the Effect of the 2014 Transplantation}

As described in the previous section, conventional cultural norms and practices continue to permeate many areas of Chinese society, which will invariably affect the actual workings of capital provision treatments borrowed from the US and possibly trigger a series of new and unforeseen events as spillovers. These so-called legal irritants are likely to emerge from two aspects. The first is connected with the pragmatic legislative culture and sporadic borrowing activities in China, which is doctrinally observed in the field of capital maintenance. The second type of irritant

\footnotetext{
${ }^{224}$ Certain Provisions of Commercial Registration of Shenzhen Special Economic Zone, Regulations of Commercial Registration of Zhuhai Special Economic Zone; and State Administration for Industry and Commerce's Approval on the Reform Plan of Commercial Registration of Business License of Guangdong Province.

225 Several Opinions on Supporting the Building-up of China (Shanghai) Pilot Free Trade Zone issued by the State Administration for Industry and Commerce, and Regulations of Registration Administration of Enterprises in China (Shanghai) Pilot Free Trade Zone issued by Shanghai Administration for Industry and Commerce.

226 Peerenboom (2006), p 850.

227 See comments in Zou and Chen (2014), p 19, "When scholars are still debating how Company Law should react to the State Council's plan to change the corporate registration system, legislators have already finished amending and approved Company Law [...]'.

228 Lei and Xue (2015), p 36.
} 
occurs because of the powerful socio-economic idiosyncrasies of the host, where transplanted 'law in books' is moulded to a different reality. This type of irritant is most likely to emerge in corporate financing practices following the latest legislative amendment, given that legal capital is an essential component of the financial structure of a company.

\subsection{Legislators' Distaste for Capital Maintenance}

In stark contrast to Chinese lawmakers' enthusiasm for relaxing the mandatory confines of capital provision, the connected area of capital maintenance has become a desolate field of reform-it was barely touched in the 2005 company law reform, and was completely ignored in the 2014 amendment. This was hardly because of the flawless state of the existing capital maintenance regime; on the contrary, several doctrinal loopholes were clearly noticeable in this field, a typical example being the potential opportunism generated by financial assistance provided to third parties who acquire company shares, as discussed in Sect. $4{ }^{229}$ Far more illustrative of the inadequacy of capital maintenance is the pronounced absence of any legal provision governing so-called 'hidden distributions', which are strictly prohibited in many jurisdictions. ${ }^{230}$ For instance, in the US, although the RMBCA does not explicitly prohibit this type of transfer, characterized by inadequacy and an unusual course of trade, it falls neatly into the category of 'constructive fraud' and is therefore governed by fraudulent transfer laws. ${ }^{231}$

Chinese legislators' inattention to capital maintenance may also be explained from the instrumental perspective. In comparison with capital provision rules, rules relevant to capital maintenance are of lower utility in realizing immediate socioeconomic imperatives, i.e. legitimizing and encouraging growth in private sectors, since these rules would only become relevant and applicable after private businesses are set up. However, such legislative inattention has unsurprisingly resulted in the continuity of doctrinal loopholes in the field of capital maintenance; coupled with the fact that essential ex post court-based remedies that execute similar creditor protection functions to ex ante mandates thus far have no real counterpart in China, as explained in Sect. 4. The balance between creditors and shareholders has thus been further tilted in favour of the latter, as an adverse aspect of the latest capital provision reform.

\footnotetext{
229 See above n. 130.

230 'A hidden distribution requires an exchange of economic goods between the corporation and a shareholder (or a person close to the shareholder) at terms that the corporation would not have agreed to when dealing with an unrelated third party.' Mülbert and Birke (2002), pp 703 and 706.

231 'Badges of fraud' were initially set forth in Twyne's case as grounds for fraudulent transfer litigations. Twyne's Case, 3 Coke 80b, 76 Eng. Rep. 809 (Star Chamber 1601). The focal points of fraudulent transfer are now much more broadly defined in the US regulatory system, preventing the debtor from making transfers or incurring obligations for less than reasonably equivalent value. E.g. Uniform Fraudulent Transfer Act $\S \S 4$ (a), 5 (a) and (b); 11 USC, $\S 548$ (a)(1)(A)-(B). This cause of action, named 'constructive fraud', enables courts to void certain transfers that were not made with fraudulent intent, but worked to the detriment of the creditors. Zaretsky (1995), pp 1171-1172.
} 


\subsection{Capital-Starved Start-Ups}

Even if we assume the efficiency of the recent legislative change of capital provision in stimulating business registration, there still remains the issue of corporate capitalization, as the boom in private entrepreneur activities triggered by the abolition of minimum capital calls for a greater supply of credit. It is true that Chinese legislators do not explicitly restrain the freedom of private enterprises to obtain capital, but inevitably in practice the question arises of how far a founding member with limited initial capital contribution can be said to enjoy the benefit brought about by the recent legislative change, if he is denied adequate access to loan capital. For most general creditors, the limited business size and the short credit history of start-ups simply do not merit capital provision. Even if some might be willing to offer these companies a chance, higher rates of interest would be a must. ${ }^{232}$ 'The Poor Pays More' is indeed the case for start-ups, even in the US where capital provision treatment is most liberal. A probable risk follows from this legislative change in China, in that there would likely be a shortage of affordable sources of capital for new start-ups, with correspondingly greater risks of undercapitalization.

Going one step further, the profound functional differences between SOEs and private businesses in China are not going to be altered by this legislative change, much less their differential treatments in capitalization. At the moment, four major financing sources are available (at least on paper) for all Chinese firms: domestic bank loans, firms' self-fundraising, the State budget, and foreign direct investment. ${ }^{233}$ However, in practice private enterprises receive little support from State banks, which are pressurized to prioritize credit for SOEs with a view to securing the legitimacy of the socialist regime. ${ }^{234}$ Research has shown that State banks have channelled the bulk of their loans to State firms and local government vehicles, and they will, at least in the near future, continue to strategically prioritize key industries and State-owned economic entities. ${ }^{235}$

When State banking is tight with lending credit, whether private start-ups incentivized by the changes in capital provision will be sufficiently funded counts on the capacity of private creditors. ${ }^{236}$ To their disenchantment, private banking in China is still significantly underdeveloped, as evidenced by the large percentage of government ownership in the banking sector. Up to August 2013 State-owned banks accounted for $75.2 \%$ of the total market share, and only one private bank- the Minsheng Banking Corp.-was among the country's ten largest commercial lenders. ${ }^{237}$ Although a plan has been unveiled to set up more private banks, ${ }^{238}$

\footnotetext{
232 Ramsay (2001), p 572.

233 Allen et al. (2009), p 79.

234 Welborn (2002), p 400.

235 Kevin Yao, 'China to Set Up More Private Banks to Help Small Firms', Reuters, 12 August 2013. Breslin (2011), p 1331.

236 Armour (2000), p 18.

237 Yao, above n. 235.

238 Victoria Bi and Kevin Yao, 'China Approves Pilot Plan to Set Up Private Banks', Reuters, 6 January 2014.
} 
whether financial support for cash-starved start-ups will be boosted is yet to be seen, given that the scheme is only at a pilot stage, and the China Banking Regulatory Commission and other State banking authorities have already vowed to implement 'prudential regulatory standards' 239 in approving and closely supervising the performance of these pilot private banks.

\subsection{Further Reliance on Informal Social Networks}

Where formal banking support is not conveniently accessible to new start-ups, economic actors have been quick to develop informal reputation- and relationshipbased alternatives to achieve their financing ends. ${ }^{240}$ The huge capitalization gap in China's private sectors has thus far been filled largely by an unofficial system that is vibrant, but furtive, and in most circumstances illegal, known as shadow banking. ${ }^{241}$ Along with the growth of the private sector, the financial composition in China has shifted from conventional bank domination in the 1970s, when the economy was starting to open up and banks provided more than $90 \%$ of all funding in the economy, to the recent and significant involvement of non-bank institutions, with banks now accounting for only half of all the new funding in the economy. ${ }^{242}$ Meanwhile, the complexity of the Chinese shadow banking system also indicates that increasing legal order has not completely substituted the overarching cultural feature of guanxi in China's development. Differing from the US style of shadow banking, which primarily involves 'prestigious Wall Street firms and complex financial instruments', ${ }^{243}$ household- and firm-level ventures supply the majority of the shadow banking credit in China. ${ }^{244}$ The composition of this lending network is enormously intricate, consisting of both quasi-financial institutions, including micro-loan companies and pawn shops, and distinct forms of informal financial institutions such as private money houses, folk cooperative finance-the list goes on. ${ }^{245}$

While it lacks the coercive apparatus of formal banking, such unofficial financing sources secured by close-knit social networks possess advantages of quick accessibility and simplicity-without the formal evaluation process, it is usually faster and easier to obtain credit by these routes than via banking capitalization. ${ }^{246}$ Business relations are also relatively stable, given that in a collectivized society

241 Shadow banking is defined by the Financial Stability Board as 'the system of credit intermediation that involves entities and activities [...] occurring fully or partly outside the regular banking system'. Financial Stability Board, 'Shadow Banking: Scoping the Issues', 12 April 2011, http://www. financialstabilityboard.org/publications/r_110412a.pdf; also Li (2014).

242 Simon Rabinovitch, 'China Draws up New Rules to Curb Shadow Banking Risks', Financial Times, 6 January 2014.

243 Paul Krugman, 'Will China Break', NY Times, 18 December 2011.

244 Welborn (2002), p 398.

245 Jianjun Li and Sara Hus, 'Shadow Banking in China' (Munich Personal RePEc Archive Paper No. 39441, 5 June 2012), pp 1 and 26.

246 Peerenboom (1993), p 55.
} 
social ties can be more resilient than formal business connections in times of uncertainty. As of 2011, all-system financing amounted to RMB 12.83 trillion, with shadow banking accounting for $41.7 \% .^{247}$ The Chinese characteristics of shadow banking and relationship business will thus continue to mitigate the shortage of capital provision for private entrepreneurship, which in turn will further consolidate relationship investment and promote economic development.

While the recent legislative change in capital provision may prompt a further surge in shadow banking activities to fill the capitalization gap left by conventional banking, all the adverse consequences of shadow banking are also likely to amplify. Undeniably, the underground nature of many shadow finance channels renders them beyond the sight of banking regulation, and tremendous variations in the finance offered further add to the difficulty of governance. As such, it is difficult for regulators to either assess the default risks or curb adverse social impacts-for instance, excessive speculation and asset bubbles. As revealed in practice, many shadow financiers have flagrantly attempted to get around formal banking rules, particularly the ones concerning interest rates and illegal fund-raising. ${ }^{248}$ To take the example of Wenzhou, a city famous for its small and medium enterprise development, unofficial lending has been a common business practice since the opening up of China's economy, with $89 \%$ of households and $57 \%$ of firms estimated to have borrowed money from shadow channels at some point. ${ }^{249}$ The interest rates charged by private lenders are commonly higher than official bank rates, rising to $60 \%$ annually and in certain cases even up to $180 \%{ }^{250}$ This massive informal lending network managed to take the place of banks in Wenzhou for a good length of time, but collapsed in 2011 when labour costs and raw material expenses rose, which caused bankruptcies of SME loaners and subsequent malpractice among private lenders. From 2011 to 2012, in this particular city at least ten indebted people committed suicide and two hundred people fled to other regions to escape debt. ${ }^{251}$ Because of its enormous size and growing activity in China, in the eyes of many, shadow banking already stands out as an imminent threat to financial stability. ${ }^{252}$ However, it is difficult for legislators to designate and implement prudent macro-control tools governing shadow banking operations, given that (1) little data/information is available about the precise scale, nature, and variation of the sector; and (2) it would be hard to fill the capitalization gap should

\footnotetext{
$247 \mathrm{Li}$ and Hus, above n. 245, at $\mathrm{p} 1$.

248 Ibid., at p 25, 'The phenomenon of illegally raising funds is common in China and it appears in 29 provinces or cities. From early 2005 to June 2010 there were more than 10,000 cases of illegal fundraising in China'.

249 Linda Yueh, 'The Shadowy Threat from China's Lenders', BBC News, 6 March 2014.

250 'Wenzhou Usury Alarms National Financial Climate', 30 September 2011, http://www.ecns.cn/indepth/2011/09-30/2775.shtml.

251 'Qunian Wenzhou yin Minjian Jiedai 10 Ren Zisha 200Ren Paolu' (去年温州因民间借贷10人自杀 200 人跑路) [Last Year in Wenzhou 10 Committed Suicide and 200 Fled due to Unofficial Lending], Sina News, 13 March 2012. http://finance.sina.com.cn/china/dfjj/20120313/084211574332.shtml.

252 Shadow banks 'now have assets of at least thirty trillion RMB ( $\$ 4.9$ trillion), or more than $50 \%$ of GDP'. 'China's Shadow Banks: A Moving Target', Economist, 6 September 2014. Angela Monaghan, 'Shadow Banking System a Growing Risk to Financial Stability-IMF', The Guardian, 1 October 2014.
} 
informal lending be completely banned. Risks will thus continue to lurk within the arena of shadow banking in China, spurred by the recent legislative change in capital provision.

\section{Economic Effects of the 2014 Reform and Further Reform Suggestions}

\subsection{Impacts on Boosting Private Economy Sectors}

One of the primary questions that legal transplant proponents must be invited to answer is the practical effect of a displacement. As identified in the above section, one of the primary aims of the 2014 legislative move as identified by the State Council-reducing governmental interference in marketization-has largely become rhetoric, hindered not just by the doctrinal incompatibilities to the existing rules of the game, but also by deeply-embedded ideological and cultural factors. Judging from statistics, another acclaimed goal of the 2014 reform-boosting private economic sector-has become largely a gesture rather than reality, too. While official comments praised the effect of the legislative change by citing a booming increase of the number of start-ups-a total of 4.854 million new companies registered in $2015^{253}$ and another 2.6 million new companies starting in $2016^{254}$ - the direct causation link between the number of start-ups and the legislative changes is assumed rather than conclusively proved. These official media also ignore or deliberately downplay the potential risks associated with the booming numbers, including the high failure rate of start-ups and bad loans. The real effect of the 2014 reform in terms of stimulating the private economy is perhaps better appreciated from the size and overall performance of the private sector since its implementation, which have been continually declining. As shown, the average 6.7\% GDP growth in 2015 and the first two quarters of 2016 has been powered almost entirely by the state economy. ${ }^{255}$ In the first half of 2016 private investment in China grew by just $2.8 \%$, following nearly $30 \%$ annual average growth over the past decade. ${ }^{256}$ In June 2016 it even started to wither, falling for the first time since China started tracking the data in 2004, and it seems that this trend will continue. ${ }^{257}$ Credit demands and sources available to private economic actors also shrank significantly over the past two years-statistics have shown that private sector debt has fallen from $48 \%$ of total assets in 2008 to $35 \%$ in 2015 , while the State sector rose to $53 \%$ over the same period. ${ }^{258}$ Real life figures indicate this legislative move

\footnotetext{
253 Zhang Lulu, 'China's Startup Boom: 7 New Firms Every Minute', 9 June 2015, http://www.china. org.cn/business/2015-06/09/content_35775291.htm.

254 'Premier Li Urges Further Reform of Business Registration', State Council News, 17 October 2016, http://english.gov.cn/premier/news/2016/10/17/content_281475468530616.htm.

255 'China's Economy: Strong, but for How Long?', The Economist, 15 July 2016.

256 Mark Magnier, 'The Private Pain of China's Economy', The Wall Street Journal, 9 August 2016.

257 Mark Magnier, 'The Private Pain of China's Economy', The Wall Street Journal, 9 August 2016.

258 Yuan Yang and Tom Mitchell, 'China's Private Sector Misses Out on Credit Boom', Financial Times, 3 July 2016.
} 
has been functioning more as a hospitable gesture to private economy, rather than an effective method to rebalance the economy away from state-dominated heavy industry as desired.

\subsection{Reform Suggestions}

As discussed in previous sections, the contextual specifics of China and the topdown, selective adoption of foreign norms have made the actual workings of legal capital transplants less than desirable. While the deeply embedded historical and political influences that honour the sanctity of the Party-State-led economy are unlikely to change, one can see the force and urgency of filling the doctrinal loopholes that cause problems in practice. As a first step, further ex post creditor protection means are called for to correct the imbalance between shareholders and creditors. These would include a statutory inclusion of the equitable subordination doctrine and fraudulent transfer laws, which would help alleviate the difficulties of unsecured creditor protection and address the issue of improper/excessive veilpiercing applications to private companies. Further clarity is also sought with regard to the scope of veil-piercing to improve the functionality of this ex post creditor protection means, so that the problem of selective adoption could be eliminated to the greatest possible extent.

Effective creditor protection rests heavily on companies providing adequate and accurate information. Particularly in cases concerning dwarf companies, effective ex ante disclosure of corporate capital information would raise outsiders' awareness when dealing with the company. Accompanying the current Enterprise Credit Management System, mechanisms for appraising and punishing poor-quality, incomplete, or false information disclosure should be properly designed in law, and the responsibilities of different governmental organs should be clarified. This not only would improve the quality of information disclosure, but would help alleviate the over-application of veil-piercing in judicial practice-at the moment, if shareholders and company legal representatives fail to report essential corporate information, creditors of the company do not have recourse apart from suing under Article 20 of the Company Law, which, as discussed in Sect. 4, has already been showing signs of excessive use and risks destabilizing the foundation of modern company law - the sanctity of the separate legal personality doctrine. ${ }^{259}$ Additionally, given the fact that companies can now opt out of disclosing most of their essential financial information, the scope of information that enterprises are required to disclose should be expanded. These developments will heighten current and potential creditors' awareness of the concerned company's financial situation, and work to circumvent the fraudulent activities spurred by information asymmetries.

With regard to the legislative process, adopting a collaboratively dialogic approach that facilitates discussion between different state and non-state actors would help fill the doctrinal loopholes, and promote acceptance of the legislative development between various social forces. Most importantly, it would contribute to achieving the ongoing institutional reform plan of the State Council—transforming

259 Supra notes 141-147, also Hawes et al. (2015), p 19. 
the function of the government and reducing arbitrary government intervention in law-making and marketization. Although the above suggested measures would not elevate the private economic sector to the same primary standing as the state economy, which is endemic to China's socio-political setting, at least they would help in terms of eliminating doctrinal loopholes, providing more effective redress means to unsecured creditors, allowing greater transparency in business information, and ensuring more public supervision of corporate operations and legislative progress.

\section{Concluding Remarks}

The focus of long-standing theoretical and doctrinal debates, the mobility of laws continues to generate public concern today, four hundred years after Montesquieu cast justifiable doubt on the feasibility of this process. ${ }^{260}$ In light of a recent statutory modification of Chinese Company Law, which was regarded by many as imitating the capital provision arrangements in the US RMBCA, this paper considers the fit of these foreign norms to the Chinese context, in the hope of shedding light on the contentious theme of the applicability of legal transplants.

After a brief exposition of two major legal capital frameworks and the trajectory of legal capital reforms in China in Sects. 2, 3 discussed the national-specific objectives that each legal capital amendment was seeking to serve, exhibiting the instrumental feature of law in China. This was followed by a detailed evaluation of the current legal capital framework from the doctrinal lens in Sect. 4. From the doctrinal perspective, the latest legislative reform focusing on eliminating capital provision barriers is not as urgent as correcting existing structural shortfalls in the field of capital maintenance, and even creates a few more doctrinal loopholes. However, if one considers this legislative move in the context of the general socioeconomic climate of China, the borrowed provisions intending to espouse private entrepreneurship are comprehensible - as acknowledged by the Chinese government, the need to foster the private economy is real and urgent-and serve as an essential and integrated component of a State-led reform towards State-planned economic and social ends. They particularly aim to relieve the current 'cash crunch' pressures faced by Chinese banks, ameliorate excessive production capacities, and facilitate a successful economic transition from the conventional export-dominated model to one based more heavily on domestic growth. Additional to its direct stimulating effect on private entrepreneurship, the Chinese government also hopes this move will show its determination to reduce administrative interference, thus boosting investors' confidence and helping to sustain China's economic growth.

While the 2014 legislative reform of legal capital constitutes part and parcel of State-led attempts to pursue immediate socio-economic agendas, in particular the promotion of the private economy and the reduction of government interference in marketization, the initial high hopes have not been fully realised by this law-making experience. Other than the doctrinal incompatibilities between the borrowed

260 Montesquieu, above n. 19, at p 14. 
provisions and existing legal frameworks, as discussed in Sect. 4, conventional Chinese cultural norms and practices, given their continuing influence in society, also impact on the actual workings of these borrowed configurations, impeding their anticipated effect of encouraging private entrepreneurship. Sections 5 and 6 address this matter by respectively discussing the weight of national-specific contextual embeddings and resultant spillover effects of these transplanted rules. As discussed in Sect. 5, instrumentality and State centrality are rooted in China's unique sociopolitical settings, and have underpinned the whole substance and process of legislative reform. This is in stark contrast to the ideological underpinnings of the enabling US company law regime, where the legal configuration honours the sanctity of market actor autonomy over State control, and upholds a less interventionist administrative regime that constrains rather than empowers governments. $^{261}$

Under a different orientation of law, one directed towards the State rather than at private regulation, the borrowed US deregulatory formulation of legal capital will inevitably be domesticated, generating practical consequences unique to the Chinese context-i.e. the so-called irritants arising from legal transplantation discussed in Sect. 6. This section maps out two major areas where irritants will likely emerge: foreseeable capital-shortages for start-ups, and heavier reliance upon the shadow banking sector. These potential spillovers, particularly the latter, again spring from the particular socio-cultural norms of China, specifically the State-centred policy imperative and the continuing influence of Confucianism emphasizing tight-knit interpersonal relationships in Chinese society. It shows that even in the sphere of commercial law, where rules are regarded as easily transferable, deeply engrained legal ideologies may set boundaries to the function of transplantation. As exhibited in real-life figures in Sect. 7, over the past two years, since the legislative reform, the private economic sector saw an overall decline, rather than the boom that was hoped for, and this trend is likely to continue in the foreseeable future. This article thus holds to Montesquieu's line of reasoning about the law linking with the socio-political organization of a society from the perspective of company and commercial laws, where the mobility of law view conventionally prevails. While it would be premature to rule out the will of Chinese governments to stimulate the growth of the private economy, to realize the economic structural transformation agenda and to make China's development better integrated with the rest of the world, as well as the positive impact of the 2014 legal capital reform in filling certain doctrinal loopholes, doctrinal and practical challenges still remain for the current legal capital framework to exert its full force as hoped.

Acknowledgements This research was funded by Jilin University Philosophy and Social Science Research Grant (2015FRLX10).

Open Access This article is distributed under the terms of the Creative Commons Attribution 4.0 International License (http://creativecommons.org/licenses/by/4.0/), which permits unrestricted use, distribution, and reproduction in any medium, provided you give appropriate credit to the original author(s) and the source, provide a link to the Creative Commons license, and indicate if changes were made.

261 Ginsburg (2000), p 836. 


\section{References}

Allen F, Qian J, Qian M (2005) Law, finance, and economic growth in China. J Financ Econ 77:57-116

Allen WT, Kraakman R, Subramanisn G (2009) Commentaries and cases on the law of business organization. Wolters Kluwer, Austin

Armour J (2000) Share capital and creditor protection: efficient rules for a modern company law. Mod L Rev 63:355-378

Art RC, Gu M (1995) China incorporated: the first corporation law of the People's Republic of China. Yale J Int Law 20:273-378

Bainbridge SM (2002) Corporation law and economics. Foundation Press, New York

Baird DG, Jackson TH (1985) Fraudulent conveyance law and its proper domain. Vanderbilt Law Rev 38:829-855

Bebchuk L, Roe M (2000) A theory of path dependence in corporate governance and ownership. Stan Law Rev 52:127-170

Bix B (2012) Jurisprudence: theory and context, 6th edn. Sweet \& Maxwell, London

Black B, Kraakman R (1996) A self-enforcing model of corporate law. Harv Law Rev 109:1911-1983

Breslin S (2011) The China model and the global crisis: from Friedrich List to a Chinese mode of governance? Int Aff 87:1323-1344

Calcina Howson N (2010) Judicial independence and the company law in the Shanghai courts. In: Peerenboom R (ed) Judicial independence in China: lessons for global rule of law promotion. Cambridge University, New York, pp 134-153

Carrington C (1955) Rudyard Kipling: his life and work. Macmillan, London

Chen Z (2003) Capital markets and legal development: the China case. China Econ Rev 14:451-472

Chen M (2014) Transformation of Chinese government's economic function under globalization. In: Proceedings of the International Conference on Public Management (ICPM 2014): International integration for regional public management: new challenges and opportunities. Atlantic Press, Paris, pp 146-152

Clarke D (2006) Lost in translation? Corporate legal transplants in China. GWU Law School Public Law Research Paper No 213. http://scholarship.law.gwu.edu/cgi/viewcontent.cgi? article=2259\&context= faculty_publications. Accessed 4 Sept 2017

Committee on Corporate Laws (1979) Changes in the Model Business Corporation Act-amendments to financial provisions. Bus Lawyer 34:1867-1889

Cox JC, Hazen TL (2003) Cox and Hazen on corporations: including unincorporated form of doing business. Aspen, New York

Cui W (2014) Yingye Ziyou yu Gongsi Ziben Zhidu de Biange (营业自由与公司资本制度的变革) [The freedom of business operation and the reform of legal capital]. Global Law Rev 1:150-163

Dainow J (1967) The civil law and the common law: some points of comparison. Am J Comp Law 15:419-435

De Secondat C (2001) (first published in 1748, translated by Thomas Nugent in 1752, republished in 2001) Baron de Montesquieu, The spirit of laws. Batoche Books, Ontario

Department of Business, Innovation \& Skills (2012) Company law: providing a flexible framework which allows companies to compete and grow. https://www.gov.uk/government/uploads/system/uploads/ attachment_data/file/31649/12-560-company-law-flexible-framework-discussion-paper.pdf. Accessed 4 Sept 2017

Enriques L, Macey JR (2001) Creditors versus capital formation: the case against the European legal capital rules. Cornell Law Rev 86:1165-1204

Gillespie J (2002) Transplanted company law: an ideological and cultural analysis of market-entry in Vietnam. Int Comp Law Q 51:641-672

Ginsburg T (2000) Does law matter for economic development? Evidence from East Asia. Law Soc Rev 34(3):829-856

Grosman A, Okhmatovskiy I, Wright M (2016) State control and corporate governance in transition economies: 25 years on from 1989. Corp Gov Int Rev 24:200-221

Haley J (2006) Law and culture in China and Japan: a framework for analysis. Mich J Int Law 27:895915

Hamilton GG (1990) Patriarchy, patrimonialism, and filial piety: a comparison of China and Western Europe. Br J Sociol 41:77-104

Hansmann H, Kraakman R (2000-2001) The end of history for corporate law. Geo Law J 89:439-468 
Hassen R (2009) Empires of speed: time and the acceleration of politics and society. Leiden, Brill

Hawes C, Lau AKL, Young A (2015) Introducing the 1-yuan Chinese company: impacts of the 2014 PRC company law amendments on shareholder liability and creditor protection. https://papers.ssrn.com/ sol3/cf_dev/AbsByAuth.cfm?per_id=503318. Accessed 4 Sept 2017

Horowitz MJ (1977) The transformation of American law, 1780-1860. Harvard University, Cambridge

Huang S-c (1999) Essentials of neo-Confucianism: eight major philosophers of the Song and Ming periods. Greenwood, Westport

Huang H (2012) Zhongguo Gongsifa Renge Fouren Zhidu Shizheng Yanjiu (中国公司法人格否认制度 实证㸴究) [An empirical study on the veil-piercing system in China]. J Legal Stud 1:3-16

Jensen LM (1997) Manufacturing Confucianism: Chinese traditions and universal civilization. Duke University, Durham

Jiang P (2014) Gongsi Zhuce Ziben Zhidu Gaige Shuping (公司注册资本制度改革述评) [A Synthesis of the legal capital reform]. China Commercial Law Yearbook. http://www.cqlsw.net/apply/company/ 2015081017099.html. Accessed 4 Sept 2017

Kahn-Freund O (1974) On uses and misuses of comparative law. Mod L Rev 37:1-27

Kennedy S (2010) The myth of the Beijing consensus. J Contemp China 19:461-478

Keung Ip P (2009) Is Confucianism good for business ethics in China? J Bus Ethics 88:463-476

Kohl H (1999) Path dependence and German corporate law: some sceptical remarks from the sideline. Colum J Eur Law 5:189-198

Lan G (2014) American legal realism goes to China: the China puzzle and law reform. Am Bus Law J 51:365-427

Legrand P (1997) The impossibility of legal transplants. Maastricht J Eur Comp L 4:111-124

Lei X, Xue B (2015) Gongsi Ziben Zhidu Gaige: Xianshi Pingjia yu Weilai Zouxianag (公司资本制度改 革:现实评价与未来走向) [The reform of legal capital: realistic evaluations and future directions]. Gansu Soc Sci 2:122-127

Levi-Faur D (1997) Economic nationalism: from Friedrich List to Robert Reich. Rev Int Stud 23:359-370

Li T (2014) Shadow banking in China: expanding scale, evolving structure. J Fin Eco Pol'y 6:198-211

Li J (2015) Gongsi Ziben Zhidu de Xinfazhan (公司资本制度的新发展) [The new development of legal capital rules]. CUPL Press, Beijing

Liss KJ (1987) Fraudulent conveyance law and leveraged buyouts. Colum Law Rev 87(7):1491-1514

Liu J (2013) Nian Xingongsifa Shi Dazao Zhongguo Jingji Shengjiban de Falv Jishi (2013年新公司法是 打造中国经济'升级版'的法律基石) [The 2013 New Company Law is the legal cornerstone of China's economic development]. 12 May 2014. http://lad.ccpit.org/second/index.aspx?nodeid= 47\&page $=$ ContentPage\&contentid $=1777$. Accessed 4 Sept 2017

Liu Y (2014) Gongsifa Ziben Zhidu Gaige de Luoji yu Lujing (公司法资本制度改革的逻辑与路径) [The logic and path of the legal capital reform in the company law context]. Legal Res 5:32-56

Llewellyn KN (1930) A realistic jurisprudence-the next step. Colum Law Rev 30:431-465

Locke J (first published 1690, republished 1988) Two treaties of government. Cambridge University Press, Cambridge, chap II, sect 6

Mao Z (1927) Hunan Nongmin Yundong Kaocha Baogao (湖南农民运动考察报告) [The report on Hunan peasant movement]. http://www.china.com.cn/guoqing/2012-08/29/content_26367138.htm. Accessed 4 Sept 2017

Marx K, Engels F (1996) From the communist manifesto. In: Yarrow GK, Jasinski P (eds) Privatisation: critical perspectives on the world economy, vol I. Routledge, New York, pp 102-105

Mauss M (1995) Essai sur le don. Sociologie et anthropologie, 6th edn. PUF, Paris, pp 274-275

Mei-Hui Yang M (2002) The resilience of guanxi and its new deployment: a critique of some new Guanxi scholarship. China Q 170:459-476

Miles L (2006) The application of Anglo-American corporate practices in societies influenced by Confucian values. Bus Soc Rev 111:305-322

Mülbert PO, Birke M (2002) Legal capital—is there a case against the European legal capital rules? Eur Bus Org L Rev 3:695-732

Naughton B (2010) China's distinctive system: can it be a model for others? J Contemp China 19:437460

North D (1991) Institutions, ideology, and economic performance. Cato J 11:477-488

Orts EW (2001) The rule of law in China. Vanderbilt J Transnatl Law 34:43-115

Örücü E (2002) Law as transposition. Int Comp Q 51:205-223

Peerenboom R (1993) What's wrong with Chinese rights? Toward a theory of rights with Chinese characteristics. Harv Hum Rights J 6:29-57 
Peerenboom R (2002) Let one hundred flowers bloom, one hundred schools contend: debating rule of law in China. Mich J Int Law 23:471-544

Peerenboom R (2003) Beyond universalism and relativism: the evolving debates about 'values in ASIA'. Ind Int Comp Law Rev 14(1):1-85

Peerenboom R (2006) What have we learned about law and development? Describing, predicting, and assessing legal reforms in China. Mich J Int Law 27:823-871

Peerenboom R (2010a) Introduction. In: Peerenboom R (ed) Judicial independence in China-lessons for global rule of law promotion. Cambridge University Press, New York, pp 1-22

Peerenboom R (2010b) Judicial independence in China: common myths and unfounded assumptions. In: Peerenboom R (ed) Judicial independence in China: lessons for global rule of law promotion. Cambridge University, New York, pp 69-94

Peerenboom R (2015) Fly high the banner of socialist rule of law with Chinese characteristics. Hague J Rule Law 7:49-74

Prado M, Trebilcock M (2009) Path dependence, development, and the dynamics of institutional reform. Univ Toronto Law J 59:341-380

Purcell EA Jr (1969) American jurisprudence between the wars: legal realism and the crisis of democratic theory. Am Hist Rev 75(2):424-446

Qiu Y (2006) Gongsifa Xiugai dui Ziben Shichang de Jiji Yingxiang (《公司法》修改对资本市场的积 极影响) [Positive influences of the company law reform upon securities Markets]. http://www.csrc. gov.cn/pub/newsite/flb/lfzl/jnlfssyzn/yjyd/200701/t20070108_77316.html. Accessed 4 Sept 2017

Qu T (2003) Zhongguo Falv yu Zhongguo Shehui (中国法律与中国社会) [Chinese law and Chinese society]. The Commercial Press, Beijing

Ramsay I (2001) Commentary: the politics of commercial law. Wis Law Rev 3:565-575

Redish MH, Cisar EJ (1991) 'If angels were to govern': the need for pragmatic formalism in separation of powers theory. Duke Law J 41:449-506

Sealy L, Worthington S (2010) Sealy and Worthington's cases and materials in company law, 9th edn. Oxford University, Oxford

Tamanaha BZ (1995) The lessons of law-and-development studies. Am J Int'1 L 89:470-481

Tang L (2016) The China model and its efficacy in a comparative context. J Chin Gov 1:174-187

Teubner G (1998) Legal irritants: good faith in British law or how unifying law ends up in new divergences. Mod Law Rev 61:11-32

Tomasic R (2015) Company law implementation in the PRC: the rule of law in the shadow of the state. J Corp Law Stud 15:285-309

Toms S, Wright M (2005) Divergence and convergence withinAnglo-American corporate governance systems: evidence from the US and UK, 1950-2000. Bus Hist 47:267-295

Tushnet M (1991) Critical legal studies: a political history. Yale Law J 100:1515-1544

Wacks R (2012) Understanding jurisprudence: an introduction to legal theory, 3rd edn. Oxford University, Oxford

Wang C (2008) Cong Jihuajingji dao Shehuizhuyi Shichangjingji de Weida Biange (从计划经济到社会 主义市场经济的伟大变革) [A great transformation from the state-planned economy to Socialist Market Economy]. Xinxiang Review 11:29-31. http://cpc.people.com.cn/GB/68742/127229/ 127250/8344596.html. Accessed 18 July 2016

Wang L (2012) The judging criteria and regulation of corporate litigation (公司诉讼裁判标准与规范). Renmin Publishing, Beijing

Wang Q, Hacket R, Cui X, Zhang Y (2012) Cultural differences and applicants' procedural fairness perceptions: a test of a Chinese culture-based model. Chin Manag Stud 6:350-368

Welborn JW (2002) Book review: back-alley banking: private entrepreneurs in China. Cato J 22:398-401

Wen S (2014) The ideals and reality of a legal transplant-the veil-piercing doctrine in China. Stan J Int Law 50:319-358

White Z (2006) The paradox of corruption as antithesis to economic development. Asian-Pacific Law Pol'y J 8:1-34

Williams CA, Conley JM (2005) An emerging third way? The erosion of the Anglo-American shareholder value construct. Cornell Int Law J 38:493-552

Winefield R (1987) Never the Twain shall meet-the communications debate. Gallaudet University, Washington, DC

Xi C (2006) In search of an effective monitoring board model: board reforms and the political economy of corporate law in China. Connecticut J Int Law 22:1-46 
Xu L (2015) Qiye Niandu Baogao Gongshi Zhidu Shishi Xianzhuang ji Wanshan Duice Yanjiu (企业年 度报告公示制度实施现状及完善对策㸴究) [Research on the implementation of the enterprise annual report disclosure system and reforming suggestions]. Leg Vis 3:22-24

Yeung IYM, Tung RL (1996) Achieving business success in Confucian societies: the importance of guanxi (connections). Organ Dyn 25:54-66

Zaretsky BL (1995) Fraudulent transfer law as the arbiter of unreasonable risk. South Carolina Law Rev 46:1165-1202

Zhang B, Wang Y (2014) Jian Wei Zhi Zhu, Buzhi yu Fa (见微知著 不止于法) [Tiny Clues Help Reveal the General Trend: Applications beyond Laws]. China Judgement 7:96

Zhao Y (2013) Lun Pochan Fenpei zhong de Hengpingjuci Yuanze (论破产分配中的衡平居次原则) [A discussion of the equitable subordination principle in bankruptcy allocations]. Hebei Leg Stud 3:156-161

Zhao X (2014) Ziben Zhidu Biange xia de Ziben Falv Zeren (资本制度变革下的资本法律责任) [Legal liabilities under the reform of legal capital regime]. Legal Research 5:18-31

Zhao J, Wen S (2013) Gift giving, guanxi and confucianism in a harmonious society: what Chinese law could learn from English law on aspects of directors' duties. Co Lawyer 34:381-389

Zheng W (2010) Transplanting antitrust in China: economic transition, market structure, and state control. Univ $\mathrm{Pa} \mathrm{J}$ Int Law 32(2):643-721

Zou H, Chen J (eds.) (2014) Gongsi Ziben Zhidu de Xiandaihua (公司资本制度的现代化) [The modernisation road to Chinese corporation law]. Social Science Academic Press (China), Beijing

Zuckert M (1996) The natural rights republic. University of Notre Dame Press, Notre Dame 